\title{
THE EFFECT OF LATERAL LIFTING TASKS ON HAND GRIP AND PINCH STRENGTH MEASUREMENTS
}

\author{
Joe Yee Tan ${ }^{1}$, Azrul AzWAn Bin Abdul RAHMAn ${ }^{2 *}$, \\ NADIAH BINTI AHMAD ${ }^{3}$ AND ARFAUZ BIN A. RAHMAN ${ }^{3}$ \\ ${ }^{I}$ Faculty of Manufacturing Engineering \\ ${ }^{2}$ Advanced Manufacturing Centre \\ ${ }^{3}$ Centre of Smart System and Innovative Design, \\ Faculty of Manufacturing Engineering, \\ Universiti Teknikal Malaysia Melaka, Malaysia.
}

*Corresponding author: azrulazwan@utem.edu.my

(Received: $7^{\text {th }}$ July 2020; Accepted: $16^{\text {th }}$ November 2020; Published on-line: $4^{\text {th }}$ July 2021)

\begin{abstract}
In lateral material handling tasks, which is very common in industries, warehouse systems, and other sectors, the workers can lead to work-related musculoskeletal disorders (WMSDs) because of the task and work designs, especially in upper extremities. WMSDs in hand, wrist, and fingers cause workers to have health problems, in pain and uncomfortable, hence decrease their working productivity and efficiency. The workstations distances are one of the factors that might affect workers when they perform manual material handling laterally, which can lead to WMSDs in hands. Hence, there is a need to study the relationship between transfer distances with the hand grip and pinch strengths. An experiment was carried out with 30 male participants to identify the relationship of lateral transfer distances with the hand grip and pinch strengths. The results obtained from the experiment were further investigated and analysed by using repeated measure one-way MANOVA and graphs. The results had proved that in the distances of $1.0 \mathrm{~m}, 1.25 \mathrm{~m}$ and $1.5 \mathrm{~m}$ did not affect one's hand grip and pinch strengths. But, the postures and movements were varied based on distances.
\end{abstract}

ABSTRAK: Pengangkutan barang atau bahan secara lateral amat biasa dalam industri, gudang dan sektor-sektor lain, dan kerja ini akan menyebabkan pekerja menghadapi penyakit gangguan muskuloskeletal berkaitan kerja (WMSDs) terutamanya di bahagian tangan. WMSDs yang melibatkan tangan dan jari menyebabkan pekerja mempunyai masalah kesihatan secara kekal dan mengalami kesakitan serta tidak-keselesaan. Secara tidak langsung, masalah ini telah mengurangkan prestasi mereka ketika bekerja. Syarikat terpaksa memberi bayaran yang tinggi kepada pekerja untuk kos perubatan and mengalami kerugian besar kerana pekerja yang tidak datang bekerja disebabkan penyakit tersebut. Jarak antara dua stesen kerja adalah faktor yang menyebabkan penyakit ini dihadapi oleh pekerja. Oleh itu, kajian diperlukan untuk mengkaji hubungan antara jarak dan kekuatan genggaman tangan serta jari. Satu esperimen yang melibatkan 30 orang lelaki responden telah dijalankan untuk mengenal pasti hubungan antara jarak dan ganggaman tangan serta jari. Hasil daripada esperimen telah dikaji dan dianalisiskan dengan menggunakan MANOVA dan grafs. Hasil kajian telah membuktikan bahawa jarak dalam $1.0 \mathrm{~m}, 1.25 \mathrm{~m}$ dan $1.5 \mathrm{~m}$ tidak membawa apa-apa kesan terhadap genggaman tangan dan jari. Cara dan pergerakan responden adalah berbeza dan disebabkan oleh jarak, walaubagaimanapun, cara dan pergerakan responden tidak membawa sebarang kesan terhadap kekuatan genggaman tangan dan jari mereka.

KEYWORDS: lateral lifting tasks; transfer distance; hand grip strength; pinch strength; postures; movements 


\section{INTRODUCTION}

Work-related musculoskeletal disorders (WMSDs) are a group of painful disorders of muscles, tendons, and nerves, for example, carpal tunnel syndrome, tendonitis, thoracic outlet syndrome, and tension neck syndrome (Canadian Centre of Occupational Health and Safety, 2018). WMSDs are also commonly called repetitive motion injury, repetitive stress injury and overuse injury, which had indicated that WMSDs are caused by a singular cause for damage to the musculoskeletal system, which is repetition and stress. Almost all work requires the use of the arms and hands. Therefore, most of the WMSDs affect the hands, wrists, elbows, neck, and shoulders. However, work using the legs can lead to WMSD of the legs, hips, ankles, and feet. Some back problems also result from repetitive activities [1].

Work tasks that are high in frequency and involve repetitive movements or activities with awkward postures that cause WMSDs bringing the effects on human muscles which may be painful during work or at rest. However, the traumatic injuries of the muscles, tendons, and nerves due to accidents are not considered to be WMSDs [2]. Manual material handling is a task that required in almost all working environments, for examples workers in construction, agriculture, hotels, factories, warehouses, building sites, farms, hospitals, offices and restaurants, where the tasks are most likely to be exposed to heavy loads for a long period and repetitive works which lead to cumulative disorders due to gradual and cumulative deterioration of the musculoskeletal system[3].

Lateral lifting tasks are considered one of the manual material handling tasks, which had indicated highly repetitive lifting movements. In lateral manual lifting tasks, the repetition of discomfort body postures and the overexertion of the force of loads cause the contracted muscles to squeeze the blood vessels and limit the flow of blood down to the working hand muscles. The reduced blood supply causes muscle fatigue, making hands and fingers more prone to injury [4]. The challenge faced by ergonomists are repetitive lifting tasks cannot be avoided, hence the range of the postural deviations and moments in forwarding flexion can be reduced by raising lift origins and destinations positions [5]. However, the lateral transfer distances and the load weights are hard to control and determined.

The workplace design plays a crucial role in the development of a WMSD. Certain workplace conditions, for example, the layout of the workstation, the speed of work especially in conveyor-driven jobs, and the weight of the objects being handled are important because these factors highly influence the risk factors and the conditions of the workers [2].

A workstation is a place a worker occupies when performing a job. The workstation may be occupied all the time, or it may be one of several places where work is done. The distances between workstations are very important because it is the factor that might cause WMSDs in workers [6]. If the workstation is properly designed, the worker should be able to maintain a correct and comfortable body posture [7]. Therefore, the distances between the workstations needed to investigate and find out how distances can affect human hand activities and strengths.

The bending of fingers and force exerts onto the hand by the load when carry in certain distances repetitively will also bring the effect of WMSDs of hands and fingers. A longer time is needed to recover when extra forces are exerted onto the muscles. There is insufficient time for recovery during repetitive work, hence increasing in forceful movements increases muscle fatigue speed [2]. Repetitive movements together with extra forces are dangerous and can lead to permanent WMSDs when involved in the same joints 
and muscle groups over and over with the same motion for too long. The survey carried out by CPWR (2018) had been proved that the rate of overexertion injuries resulting in days away from work in 2015 in transportation sectors is the highest [8].

The costs of MSDs needed for employees for treatments are the highest among the others in 2013, in which the annual costs are 80 billion USD for only workers in United State [9]. Based on the 2016 Liberty Mutual Workplace Safety Index, workplace injuries and accidents that cause employees to miss six or more days of work cost U.S. employers nearly 62 billion USD in 2013. The injuries caused by overexertion involving outside sources are the highest with $24.4 \%$ of the total cost of the most disabling workplace injuries or 15.08 billion USD among others. This high cost paid by companies for overexertion injuries is considered too high and hence WMSDs that caused by overexertion should be decreased by preventions and improvements.

WMSDs can be prevented and decrease if appropriate methods and preventions are done. Certain improvements and modifications on lateral manual handling tasks in industries can be done to decrease the effect on the hand grip and pinch strengths and improve efficiency. Therefore, studies and experiments can be carried out to identify the effect of transfer distances and load weights in lateral lifting task.

\section{METHODS}

\subsection{Participants}

A total of thirty healthy right-handed male participants (mean age was $21 \pm 3$ years, mean body mass was $75 \pm 15 \mathrm{~kg}$ and mean height $175 \pm 10 \mathrm{~cm}$ ) were recruited as subjects for the experiments. All the subjects were non-smokers and free of any history of upperextremities musculoskeletal disorders or any injuries that might affect the way they performed the tasks. All the subjects were given an informed consent form and participation form for the details of the experiments. All participants were volunteers.

\subsection{Equipment and Tools}

\subsubsection{Jamar Hand Dynamometer and Pinch Meter Gauge}

Jamar hand dynamometer was used as presented in Fig. 1 to measure the hand grip strength of participants before and after the experiment in this study. Ven-Stevens et al. [10] mentioned that grip strength is defined as the measurable ability to exert pressure onto an object or the force applied by the hand and fingers. During manual tasks, muscles are contracting much harder with excessive force, thus causes stress on the muscles, tendons, and joints. The amount of force exerted onto the objects depends on the type of grip, the weight of an object, body posture, the type of activity and the duration of the task [11].

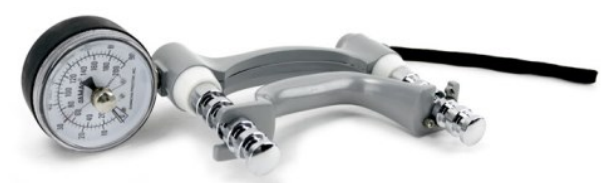

Fig. 1: Jamar hand dynamometer.

There are three types of forearm positions when hand grip strength is measured, which is pronation, neutral and supination. In this study, the forearm neutral position (Fig. 2) was chosen because this is the posture of the hands when carried out lateral lifting tasks. 


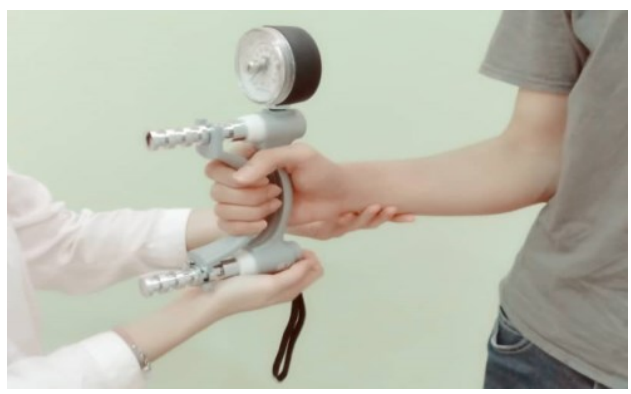

Fig. 2: The position of participant's hand grip strength forearm neutral position.

Jamar pinch meter gauge was used as presented in Fig. 3 to measure the pinch strength of participants before and after the experiment. There are three types of pinch prehension which are lateral pinch (key pinch), three-point pinch (Palmer, three-jaw chuck pinch), and two-point pinch (tip to tip pinch) [12].

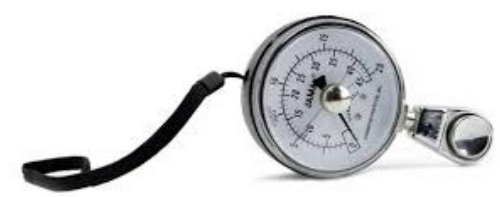

Fig. 3: Jamar pinch meter.

The pinch strength was measured in the lateral pinch position (Fig. 4) in this study due to the finger posture of carried out lateral lifting tasks. Petersen et al. [13] previously had tested the "10\% rule" which stated that the dominant hand possesses $10 \%$ greater grip strength than the non-dominant hand. However, the study had concluded that the $10 \%$ rule is only valid for right-handed persons and grip strengths are equivalent in both hands for left-handed persons. The concept is explained by the bilateral difference in the right-handed will be increased by the differential stress due to hand dominance and reduced in the lefthanded persons [13].

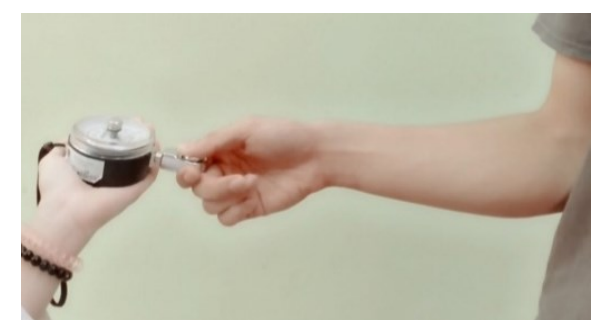

Fig. 4. The position of participant's pinch strengths lateral pinch position was taken.

\subsubsection{Loads and Workstations}

A total of six units of A4 paper boxes with handle were prepared where each box was weighed $10 \mathrm{~kg}$. Two tables were placed as the workstations for the participants to carry out the lateral lifting tasks. The marking of the lateral distances on the floor for experiment purposes was using the clothes tape. Measuring tape and weighing scale were used to measure the height of the participants, distances between two workstations (tables) and weight of the participants.

\subsection{Participant Counterbalance}


According to Zeelenberg and Pecher [14], sequential effects happen when performance in the current condition is affected by the conditions preceding it. Hence, the counterbalance condition of the trials is important in order to minimize the sequential effects of the trials and unwanted order effects from causing differences between conditions. There are three different lateral distances to be studied, hence there is three arrangement of the trials $(3 !=$ $3 \times 2 \times 1=6$ ) for both neutral forearm position of hand grip strength measurements and lateral pinch strength measurements. Figure 5 showed the tree diagram of counterbalancing of all 3 lateral distances. Counterbalancing is performed by creating Latin squares [14]. The measurement for the first participant would follow the first arrangement, the second participant would follow the second arrangement and so on. The arrangement process was repeated every 6 participants.

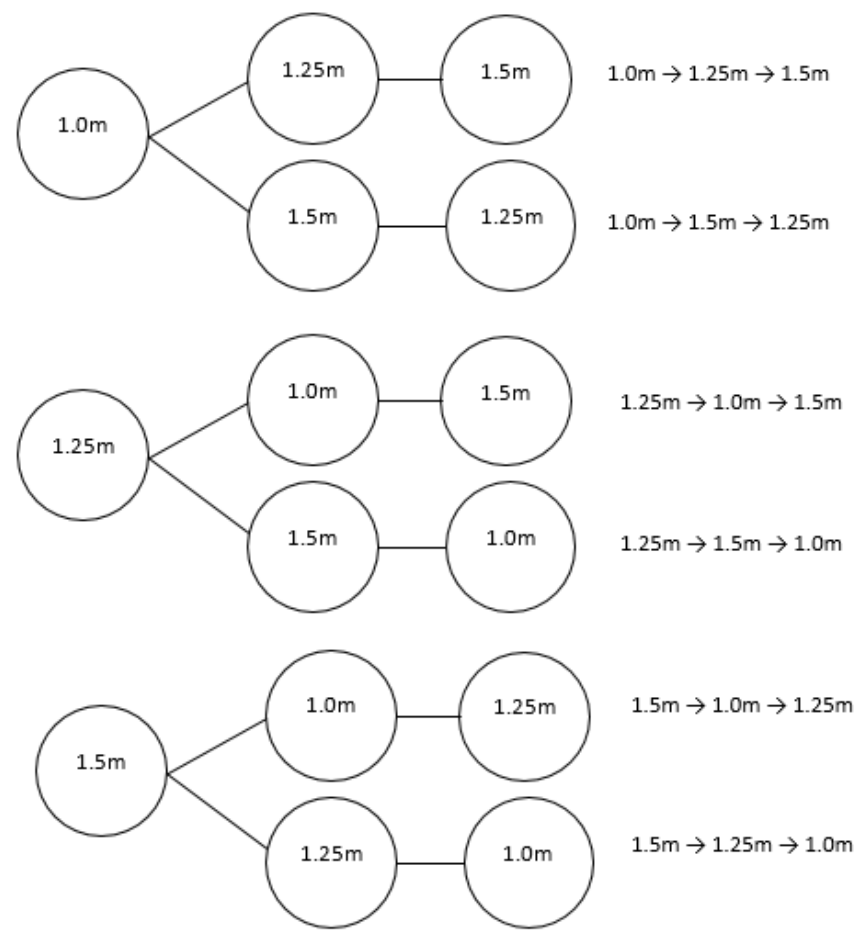

Fig. 5: Tree diagram for 6 trials counterbalances arrangements in the experiment.

\subsection{Experimental Procedures}

\subsubsection{Preparations for Experiments}

Six boxes of $10 \mathrm{~kg}$ were prepared with proper handles. Two tables with a height of $82.66 \mathrm{~cm}$ were prepared and put side to side with specific distances in between (Fig. 6). The distances of $1.0 \mathrm{~m}, 1.25 \mathrm{~m}, 1.5 \mathrm{~m}$ were marked by using a cloth tape. The box was placed align with the bench horizontal edge. Before the participants arrived, it was necessary to ensure that the tools needed in the experiments are in good condition and precise scales. The Jamar Hand Dynamometer and Pinch Meter Gauge were checked and make sure that the equipment was working properly. Every time before running an experiment on a participant, the checking had been done once. The gauge needle needed to be in the box that contained the number zero but should not touch the stopper. Before the experiment begins, the participant's hand grip and pinch strength were measured. The measurements were taken twice for each hand grip and pinch strength for both hands and the larger value was calculated and recorded. 


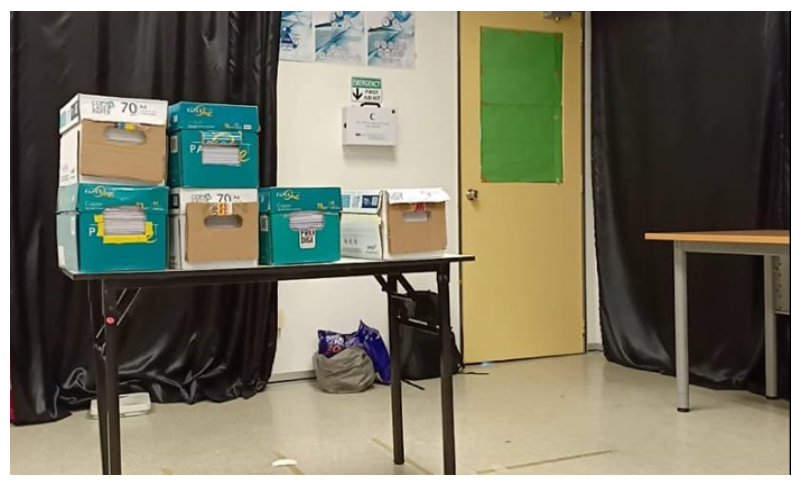

Fig. 6: Six boxes were prepared, and two tables were placed $1.25 \mathrm{~m}$ apart.

\subsubsection{Preparations for Experiments}

The distances that the participants would be carried out first were following the counterbalance sequences that had been distributed to the participants. The participant was required to stand still in the middle of the two benches and facing the front (Fig. 7). The participant required to hold the handle of the box and transfer the box by using both hands from right to left in a single direction only. The boxes were picked up from the first table to the second, which the first table located on the right side was the origin position. The second table that acted as the destination position was continuously empty for participants to place the boxes (Fig. 8). After the three types of distances had been finished by the participants, the survey forms were distributed to the participants and the participants were required to answer the survey immediately.

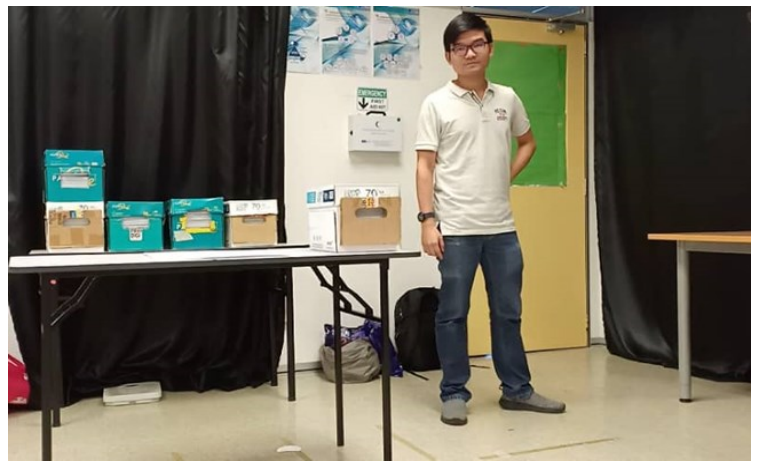

Fig. 7: A participant standing in the middle of two tables.

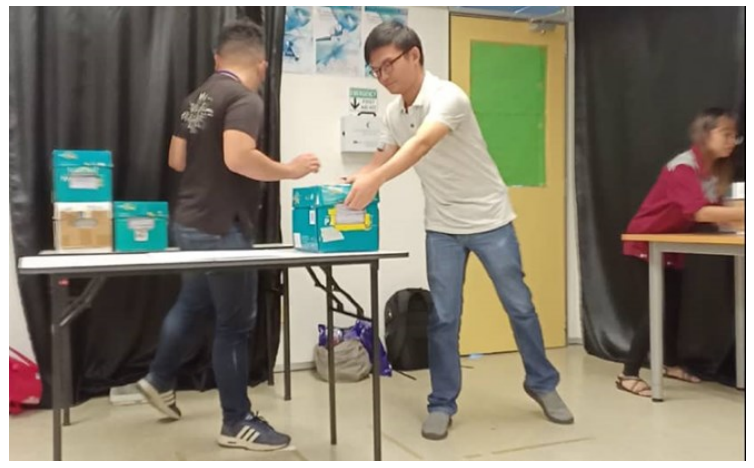

Fig. 8: A participant transferring the boxes from right to left and the second table was continuously emptied.

\subsection{Measurements}

\subsubsection{Hand Grip and Pinch Strengths Measurements}

The arrangement of the hand grip and pinch strength data to be measured would follow the counterbalance sequencing design of the experiment. After each set of lateral distance's lifting task was carried out, the hand grip and pinch strength were measured again for twice each for both hands based on the same postures of hand and finger fixed during the measurements of hand grip and pinch strengths before the experiment started. The larger value between two readings taken for the hand grip and pinch strength measurement each was chosen for the analysis phase. The participants were given to rest one minute after each reading. The hand grip and pinch strength were read in kilograms and recorded in the 
participant form for further analysis. The postures and movements of participants were also been observed and recorded.

\subsubsection{Qualitative Data Collections}

During the survey session, the participants were given questionnaires and required to answer some questions that can provide useful information and confirmation on the quantitative data that had collected. The survey was carried out in Likert scale format and the questionnaires were collected and transferred into Microsoft Word and Excel for further analyzation. The postures and movements of the participants were observed and recorded in the participation form. The postures and movements of participants were focussed on the way the participants transfer load, especially the legs.

\subsection{Statistical Analysis}

The statistical analysis involved both hand grip and pinch strength measurements (quantitative data) and qualitative data. The comparison of forces of hand grip and pinch strength before and after the experiments had done by constructing the statistical analysis on the data gathered and collected during the experiment sessions. The multivariate analysis of variance (MANOVA) method was used to investigate the inter-relationship between one factor with the hand grip strength data and pinch strength data. The repeated measure oneway MANOVA test had been chosen to analyze how the transfer distance can affect the hand grip and pinch strengths. The repeated measure was chosen because the same group of participants was tested all along with the experiment. The MANOVA test was conducted by using SPSS (IBM SPSS Statistics v26.0.0).

There were some assumptions in order to perform the one-way MAVOVA test, which was the data must be a normal distribution. A normality test is used to test and ensure that the data were normally distributed. MANOVA test was also used to examine that there was a reduction in the hand grip and pinch strength data before and after the experiments. The percentages of reduction of forces were calculated and tested to identify the differences between the percentages for the distances.

The information gathered from the survey forms (qualitative data) were interpreted by using Microsoft Excel. The results were analyzed and generated into bar charts, pie charts, and line graphs that represented the participants' percentages of perceptions on the hand grip and pinch strengths after the experiment. The results obtained from the qualitative data analysis were being compared with the results obtained from the quantitative statistical analysis to find out the relationships. Besides, the observations data were also transferred into Microsoft Excel for analysis purposes and generated using bar charts and line charts. The results were compared to identify the relationship between the distances and the postures with hand grip and pinch strengths.

\section{RESULTS}

\subsection{Shapiro-Wilk Test}

The statistical analysis of MANOVA has certain assumptions to be fulfilled before running the analysis, which included normality testing to ensure that the raw data collected is in normal distribution. The raw data were transferred into an Excel file format in terms of ages, races, body weights, body heights, hand grip readings and pinch strength readings as shown in Table 1, Table 2 and Table 3. 
Table 1: Participants data collection for hand grip strength of both hands before and after experiments

\begin{tabular}{|c|c|c|c|c|c|c|c|c|c|c|c|c|c|c|c|c|c|}
\hline \multirow[b]{2}{*}{ No. } & \multirow{2}{*}{$\begin{array}{c}\text { Age } \\
{[y, \mathbf{m}]}\end{array}$} & \multirow{2}{*}{$\begin{array}{c}\text { Weight } \\
\text { [kg] }\end{array}$} & \multirow{2}{*}{$\begin{array}{c}\text { Height } \\
\text { [m] }\end{array}$} & \multicolumn{14}{|c|}{ Hand Grip } \\
\hline & & & & $\begin{array}{c}\text { Initial } \\
\mathbf{R}\end{array}$ & $\begin{array}{c}\text { Initial } \\
\mathbf{L}\end{array}$ & $\begin{array}{c}1.0 \mathrm{~m} \\
\mathrm{R}\end{array}$ & $\begin{array}{c}\% 1.0 \mathrm{~m} \\
\text { R }\end{array}$ & $\begin{array}{c}1.0 \mathrm{~m} \\
\mathrm{~L}\end{array}$ & $\begin{array}{c}\% 1.0 m \\
\quad L\end{array}$ & $\begin{array}{c}1.25 \mathrm{~m} \\
\mathbf{R}\end{array}$ & $\begin{array}{c}\% 1.25 \mathrm{~m} \\
\mathrm{R}\end{array}$ & $\begin{array}{c}1.25 \mathrm{~m} \\
\mathrm{~L}\end{array}$ & $\begin{array}{c}\% 1.25 \mathrm{~m} \\
\mathrm{~L}\end{array}$ & $\begin{array}{c}1.5 \mathrm{~m} \\
\mathrm{R}\end{array}$ & $\begin{array}{c}\% 1.5 m \\
R \\
\end{array}$ & $\begin{array}{c}1.5 \mathrm{~m} \\
\mathrm{~L}\end{array}$ & $\begin{array}{c}\% \text { 1.5m } \\
\quad \mathrm{L} \\
\end{array}$ \\
\hline 1 & 21,10 & 54 & 1.69 & 38.00 & 32.50 & 37.00 & 2.63 & 29.00 & 10.77 & 36.00 & 5.26 & 32.00 & 1.54 & 35.00 & 7.89 & 30.00 & 7.69 \\
\hline 2 & 22,0 & 65 & 1.70 & 45.50 & 40.00 & 42.00 & 7.69 & 36.50 & 8.75 & 39.50 & 13.19 & 35.50 & 11.25 & 30.00 & 34.07 & 35.00 & 12.50 \\
\hline 3 & 21,6 & 63 & 1.76 & 39.00 & 30.00 & 32.00 & 17.95 & 31.00 & -3.33 & 31.00 & 20.51 & 30.00 & 0.00 & 36.00 & 7.69 & 30.00 & 0.00 \\
\hline 4 & 22,11 & 72 & 1.80 & 38.50 & 39.00 & 35.50 & 7.79 & 32.50 & 16.67 & 31.00 & 19.48 & 39.00 & 0.00 & 37.00 & 3.90 & 39.00 & 0.00 \\
\hline 5 & 21,10 & 57 & 1.74 & 35.50 & 31.50 & 34.50 & 2.82 & 30.00 & 4.76 & 33.00 & 7.04 & 30.00 & 4.76 & 33.00 & 7.04 & 30.00 & 4.76 \\
\hline 6 & 21,1 & 65 & 1.65 & 44.50 & 35.00 & 44.00 & 1.12 & 36.00 & -2.86 & 39.50 & 11.24 & 35.00 & 0.00 & 39.00 & 12.36 & 33.50 & 4.29 \\
\hline 7 & 21,10 & 71 & 1.76 & 33.00 & 35.00 & 27.00 & 18.18 & 35.50 & -1.43 & 32.00 & 3.03 & 36.00 & -2.86 & 28.00 & 15.15 & 30.00 & 14.29 \\
\hline 8 & 21,3 & 55 & 1.65 & 39.50 & 30.00 & 34.00 & 13.92 & 26.00 & 13.33 & 35.00 & 11.39 & 30.00 & 0.00 & 37.00 & 6.33 & 30.00 & 0.00 \\
\hline 9 & 23,11 & 75 & 1.74 & 33.50 & 29.00 & 32.00 & 4.48 & 27.50 & 5.17 & 30.50 & 8.96 & 26.00 & 10.34 & 31.50 & 5.97 & 27.00 & 6.90 \\
\hline 10 & 23,3 & 70 & 1.80 & 40.00 & 39.50 & 36.00 & 10.00 & 36.00 & 8.86 & 40.00 & 0.00 & 36.50 & 7.59 & 36.50 & 8.75 & 37.00 & 6.33 \\
\hline 11 & 23,7 & 60 & 1.68 & 34.50 & 37.00 & 29.50 & 14.49 & 32.00 & 13.51 & 33.00 & 4.35 & 33.00 & 10.81 & 33.50 & 2.90 & 34.00 & 8.11 \\
\hline 12 & 23,5 & 63 & 1.75 & 32.00 & 26.50 & 29.00 & 9.38 & 26.50 & 0.00 & 31.00 & 3.13 & 26.00 & 1.89 & 28.00 & 12.50 & 24.00 & 9.43 \\
\hline 13 & 24,0 & 70 & 1.72 & 34.00 & 35.00 & 32.00 & 5.88 & 34.00 & 2.86 & 32.00 & 5.88 & 33.50 & 4.29 & 31.00 & 8.82 & 29.00 & 17.14 \\
\hline 14 & 23,1 & 68 & 1.75 & 45.50 & 41.50 & 45.00 & 1.10 & 39.00 & 6.02 & 43.00 & 5.49 & 40.00 & 3.61 & 41.50 & 8.79 & 40.00 & 3.61 \\
\hline 15 & 23,8 & 65 & 1.62 & 40.00 & 34.50 & 36.00 & 10.00 & 30.00 & 13.04 & 35.50 & 11.25 & 32.00 & 7.25 & 37.50 & 6.25 & 30.00 & 13.04 \\
\hline 16 & 22,5 & 99 & 1.70 & 37.50 & 35.00 & 33.00 & 12.00 & 28.50 & 18.57 & 34.50 & 8.00 & 32.00 & 8.57 & 35.00 & 6.67 & 33.00 & 5.71 \\
\hline 17 & 22,11 & 66 & 1.65 & 32.50 & 30.50 & 27.00 & 16.92 & 24.00 & 21.31 & 31.50 & 3.08 & 30.00 & 1.64 & 29.50 & 9.23 & 29.50 & 3.28 \\
\hline 18 & 23,11 & 84 & 1.80 & 36.00 & 36.50 & 36.00 & 0.00 & 34.00 & 6.85 & 34.00 & 5.56 & 34.50 & 5.48 & 36.00 & 0.00 & 33.00 & 9.59 \\
\hline 19 & 22,4 & 45 & 1.65 & 34.00 & 27.00 & 32.00 & 5.88 & 26.50 & 1.85 & 31.00 & 8.82 & 25.00 & 7.41 & 30.50 & 10.29 & 24.00 & 11.11 \\
\hline 20 & 23,4 & 80 & 1.84 & 39.00 & 45.00 & 37.00 & 5.13 & 42.00 & 6.67 & 38.00 & 2.56 & 37.00 & 17.78 & 31.00 & 20.51 & 32.00 & 28.89 \\
\hline 21 & 22,6 & 80.5 & 1.65 & 52.50 & 44.00 & 45.50 & 13.33 & 40.50 & 7.95 & 50.00 & 4.76 & 44.50 & -1.14 & 44.00 & 16.19 & 39.00 & 11.36 \\
\hline 22 & 23,11 & 78.1 & 1.74 & 44.00 & 47.00 & 44.00 & 0.00 & 39.00 & 17.02 & 44.00 & 0.00 & 45.00 & 4.26 & 43.00 & 2.27 & 44.00 & 6.38 \\
\hline 23 & 23,3 & 102 & 1.65 & 42.00 & 44.00 & 41.00 & 2.38 & 37.00 & 15.91 & 40.00 & 4.76 & 35.50 & 19.32 & 41.50 & 1.19 & 44.00 & 0.00 \\
\hline 24 & 23,11 & 67.5 & 1.72 & 36.00 & 33.00 & 33.00 & 8.33 & 33.00 & 0.00 & 35.50 & 1.39 & 33.00 & 0.00 & 34.00 & 5.56 & 36.00 & -9.09 \\
\hline 25 & 22,5 & 84 & 1.72 & 26.00 & 24.00 & 21.00 & 19.23 & 23.00 & 4.17 & 22.00 & 15.38 & 20.00 & 16.67 & 20.00 & 23.08 & 18.00 & 25.00 \\
\hline 26 & 22,8 & 86.23 & 1.63 & 41.50 & 32.50 & 36.00 & 13.25 & 31.50 & 3.08 & 35.00 & 15.66 & 29.00 & 10.77 & 39.00 & 6.02 & 29.50 & 9.23 \\
\hline 27 & 23,9 & 64 & 1.70 & 37.00 & 34.00 & 34.50 & 6.76 & 32.00 & 5.88 & 35.00 & 5.41 & 34.00 & 0.00 & 36.00 & 2.70 & 28.00 & 17.65 \\
\hline 28 & 23,7 & 69 & 1.68 & 39.50 & 36.00 & 38.00 & 3.80 & 33.00 & 8.33 & 37.00 & 6.33 & 35.00 & 2.78 & 33.00 & 16.46 & 32.00 & 11.11 \\
\hline 29 & 24,1 & 65 & 1.73 & 39.50 & 33.00 & 30.00 & 24.05 & 29.00 & 12.12 & 30.50 & 22.78 & 26.50 & 19.70 & 38.50 & 2.53 & 31.00 & 6.06 \\
\hline 30 & 23,5 & 65 & 1.70 & 46.50 & 43.50 & 45.00 & 3.23 & 39.50 & 9.20 & 43.50 & 6.45 & 41.00 & 5.75 & 46.00 & 1.08 & 42.50 & 2.30 \\
\hline
\end{tabular}


Table 2: Participants data collection for pinch strength of both hands before and after experiments

\begin{tabular}{|c|c|c|c|c|c|c|c|c|c|c|c|c|c|c|c|c|c|}
\hline \multirow[b]{2}{*}{ No. } & \multirow{2}{*}{$\begin{array}{c}\text { Age } \\
{[y, m]}\end{array}$} & \multirow{2}{*}{$\begin{array}{c}\text { Weight } \\
\text { [kg] }\end{array}$} & \multirow{2}{*}{$\begin{array}{r}\text { Height } \\
\text { [m] }\end{array}$} & \multicolumn{14}{|c|}{ Pinch } \\
\hline & & & & $\begin{array}{c}\text { Initial } \\
\mathbf{R}\end{array}$ & $\begin{array}{c}\text { Initial } \\
\mathbf{L}\end{array}$ & $\begin{array}{c}1.0 \mathrm{~m} \\
\mathbf{R}\end{array}$ & $\begin{array}{c}\% 1.0 \mathrm{~m} \\
\mathrm{R} \\
\end{array}$ & $\begin{array}{c}1.0 \mathrm{~m} \\
\mathrm{~L}\end{array}$ & $\begin{array}{c}\% 1.0 \mathrm{~m} \\
\mathrm{~L}\end{array}$ & $\begin{array}{c}1.25 \mathrm{~m} \\
\mathrm{R}\end{array}$ & $\begin{array}{c}\% 1.25 \mathrm{~m} \\
\mathrm{R} \\
\end{array}$ & $\begin{array}{c}1.25 \mathrm{~m} \\
\mathrm{~L}\end{array}$ & $\begin{array}{c}\% 1.25 \mathrm{~m} \\
\mathrm{~L}\end{array}$ & $\begin{array}{c}1.5 \mathrm{~m} \\
\mathrm{R}\end{array}$ & $\begin{array}{c}\% 1.5 \mathrm{~m} \\
\mathrm{R} \\
\end{array}$ & $\begin{array}{c}1.5 \mathrm{~m} \\
\mathrm{~L}\end{array}$ & $\begin{array}{c}\% 1.5 \mathrm{~m} \\
\mathrm{~L} \\
\end{array}$ \\
\hline 1 & 21,10 & 54 & 1.69 & 9.25 & 6.75 & 8.50 & 8.11 & 6.75 & 0.00 & 8.75 & 5.41 & 6.00 & 11.11 & 9.25 & 0.00 & 6.50 & 3.70 \\
\hline 2 & 22,0 & 65 & 1.70 & 9.50 & 9.25 & 9.25 & 2.63 & 8.60 & 7.03 & 9.00 & 5.26 & 8.00 & 13.51 & 9.25 & 2.63 & 7.75 & 16.22 \\
\hline 3 & 21,6 & 63 & 1.76 & 8.00 & 7.00 & 6.25 & 21.88 & 6.00 & 14.29 & 7.00 & 12.50 & 6.50 & 7.14 & 7.25 & 9.38 & 6.25 & 10.71 \\
\hline 4 & 22,11 & 72 & 1.80 & 9.00 & 8.75 & 8.75 & 2.78 & 8.50 & 2.86 & 8.50 & 5.56 & 7.75 & 11.43 & 7.00 & 22.22 & 8.50 & 2.86 \\
\hline 5 & 21,10 & 57 & 1.74 & 9.00 & 7.25 & 8.75 & 2.78 & 6.75 & 6.90 & 8.50 & 5.56 & 7.00 & 3.45 & 8.75 & 2.78 & 6.50 & 10.34 \\
\hline 6 & 21,1 & 65 & 1.65 & 10.00 & 6.85 & 9.00 & 10.00 & 6.75 & 1.46 & 9.50 & 5.00 & 6.75 & 1.46 & 10.50 & -5.00 & 6.00 & 12.41 \\
\hline 7 & 21,10 & 71 & 1.76 & 8.50 & 6.75 & 8.25 & 2.94 & 6.25 & 7.41 & 7.25 & 14.71 & 6.50 & 3.70 & 7.50 & 11.76 & 6.75 & 0.00 \\
\hline 8 & 21,3 & 55 & 1.65 & 9.50 & 8.25 & 9.00 & 5.26 & 7.25 & 12.12 & 9.25 & 2.63 & 7.75 & 6.06 & 8.75 & 7.89 & 8.00 & 3.03 \\
\hline 9 & 23,11 & 75 & 1.74 & 9.00 & 8.85 & 7.50 & 16.67 & 7.25 & 18.08 & 9.00 & 0.00 & 7.50 & 15.25 & 7.25 & 19.44 & 7.50 & 15.25 \\
\hline 10 & 23,3 & 70 & 1.80 & 7.75 & 7.25 & 6.00 & 22.58 & 6.75 & 6.90 & 7.50 & 3.23 & 7.00 & 3.45 & 7.00 & 9.68 & 6.25 & 13.79 \\
\hline 11 & 23,7 & 60 & 1.68 & 7.50 & 6.25 & 7.25 & 3.33 & 5.75 & 8.00 & 6.25 & 16.67 & 5.50 & 12.00 & 6.75 & 10.00 & 5.00 & 20.00 \\
\hline 12 & 23,5 & 63 & 1.75 & 8.00 & 7.50 & 8.00 & 0.00 & 7.25 & 3.33 & 7.75 & 3.13 & 7.25 & 3.33 & 7.25 & 9.38 & 7.00 & 6.67 \\
\hline 13 & 24,0 & 70 & 1.72 & 8.50 & 6.75 & 7.50 & 11.76 & 6.50 & 3.70 & 7.75 & 8.82 & 6.75 & 0.00 & 8.25 & 2.94 & 6.25 & 7.41 \\
\hline 14 & 23,1 & 68 & 1.75 & 6.75 & 6.75 & 6.25 & 7.41 & 6.00 & 11.11 & 6.50 & 3.70 & 6.50 & 3.70 & 6.50 & 3.70 & 6.50 & 3.70 \\
\hline 15 & 23,8 & 65 & 1.62 & 9.50 & 8.50 & 9.50 & 0.00 & 7.50 & 11.76 & 9.50 & 0.00 & 8.00 & 5.88 & 9.50 & 0.00 & 7.75 & 8.82 \\
\hline 16 & 22,5 & 99 & 1.70 & 9.50 & 8.50 & 9.00 & 5.26 & 8.00 & 5.88 & 8.75 & 7.89 & 8.25 & 2.94 & 9.00 & 5.26 & 8.00 & 5.88 \\
\hline 17 & 22,11 & 66 & 1.65 & 9.50 & 8.00 & 7.25 & 23.68 & 6.00 & 25.00 & 7.50 & 21.05 & 6.25 & 21.88 & 8.00 & 15.79 & 8.25 & -3.13 \\
\hline 18 & 23,11 & 84 & 1.80 & 9.50 & 8.50 & 8.75 & 7.89 & 7.00 & 17.65 & 9.25 & 2.63 & 7.75 & 8.82 & 9.25 & 2.63 & 7.50 & 11.76 \\
\hline 19 & 22,4 & 45 & 1.65 & 6.00 & 4.75 & 6.00 & 0.00 & 4.25 & 10.53 & 5.75 & 4.17 & 4.15 & 12.63 & 5.25 & 12.50 & 4.50 & 5.26 \\
\hline 20 & 23,4 & 80 & 1.84 & 6.50 & 7.25 & 6.00 & 7.69 & 6.50 & 10.34 & 5.00 & 23.08 & 5.25 & 27.59 & 5.00 & 23.08 & 5.50 & 24.14 \\
\hline 21 & 22,6 & 80.5 & 1.65 & 9.25 & 7.25 & 8.25 & 10.81 & 6.75 & 6.90 & 8.25 & 10.81 & 6.75 & 6.90 & 8.00 & 13.51 & 6.50 & 10.34 \\
\hline 22 & 23,11 & 78.1 & 1.74 & 9.50 & 8.00 & 8.50 & 10.53 & 8.25 & -3.13 & 9.25 & 2.63 & 6.00 & 25.00 & 8.50 & 10.53 & 7.00 & 12.50 \\
\hline 23 & 23,3 & 102 & 1.65 & 11.75 & 10.75 & 11.00 & 6.38 & 9.00 & 16.28 & 10.25 & 12.77 & 9.75 & 9.30 & 11.50 & 2.13 & 10.00 & 6.98 \\
\hline 24 & 23,11 & 67.5 & 1.72 & 7.00 & 7.50 & 6.00 & 14.29 & 6.75 & 10.00 & 6.25 & 10.71 & 6.50 & 13.33 & 5.25 & 25.00 & 7.00 & 6.67 \\
\hline 25 & 22,5 & 84 & 1.72 & 4.75 & 4.75 & 4.00 & 15.79 & 4.00 & 15.79 & 4.25 & 10.53 & 3.75 & 21.05 & 3.75 & 21.05 & 4.00 & 15.79 \\
\hline 26 & 22,8 & 86.23 & 1.63 & 9.00 & 8.50 & 9.00 & 0.00 & 8.50 & 0.00 & 9.00 & 0.00 & 8.00 & 5.88 & 8.00 & 11.11 & 8.50 & 0.00 \\
\hline 27 & 23,9 & 64 & 1.70 & 7.50 & 6.75 & 7.25 & 3.33 & 6.50 & 3.70 & 7.50 & 0.00 & 6.50 & 3.70 & 7.25 & 3.33 & 6.25 & 7.41 \\
\hline 28 & 23,7 & 69 & 1.68 & 8.00 & 7.25 & 7.50 & 6.25 & 7.00 & 3.45 & 7.50 & 6.25 & 6.75 & 6.90 & 7.50 & 6.25 & 7.00 & 3.45 \\
\hline 29 & 24,1 & 65 & 1.73 & 9.25 & 7.50 & 9.00 & 2.70 & 7.00 & 6.67 & 9.00 & 2.70 & 6.50 & 13.33 & 9.25 & 0.00 & 7.00 & 6.67 \\
\hline 30 & 23,5 & 65 & 1.70 & 8.50 & 8.75 & 7.75 & 8.82 & 8.75 & 0.00 & 8.50 & 0.00 & 8.00 & 8.57 & 8.25 & 2.94 & 8.25 & 5.71 \\
\hline
\end{tabular}


There are two tests used in SPSS software to test the normality, which is Shapiro-Wilk and Kolmogorov-Smirnov. Since the sample size of this experiment is only 30, hence the test that chosen to test for normality in SPSS is the Shapiro-Wilk test, where the Shapiro-Wilk test is restricted for the sample size that less than 50 [15]. The normality test was run for two separate sections where the first section would be the hand grip data (Table 4) and the second section would be the pinch strength data (Table 5). In normality testing, the hypothesis was fixed as below:

\section{$H_{0}$ : The data are normally distributed.}

\section{$H_{1}$ : The data are not normally distributed.}

This hypothesis was set for both hand grip and pinch strength measurements normality tests. The p-value, which is the significance value generated by SPSS is used to determine whether the data is normally distributed. Since the confidence level of $95 \%$ is chosen, the pvalue needed to be more than 0.05 to indicate that the data is normally distributed. If the $\mathrm{p}$ value is less than 0.05 , the data is not normally distributed. The Shapiro-Wilk test result was run at confidence level of $95 \%$.

Table 3: Participants data collection for stepping during experiments

\begin{tabular}{cccccccc}
\hline No. & Age $[\mathbf{y}, \mathbf{m}]$ & Race & $\begin{array}{c}\text { Weight } \\
\text { [kg] }\end{array}$ & Height $[\mathbf{m}]$ & & Stepping & \\
\cline { 5 - 8 } & & & & & $\mathbf{1 . 0 m}$ & $\mathbf{1 . 2 5 m}$ & $\mathbf{1 . 5 m}$ \\
\hline $\mathbf{1}$ & 21,10 & $\mathrm{C}$ & 54 & 1.69 & 1 & 2 & 2 \\
$\mathbf{2}$ & 22,0 & $\mathrm{C}$ & 65 & 1.7 & 1 & 2 & 2 \\
$\mathbf{3}$ & 21,6 & $\mathrm{C}$ & 63 & 1.76 & 2 & 2 & 2 \\
$\mathbf{4}$ & 22,11 & $\mathrm{C}$ & 72 & 1.8 & 0 & 2 & 2 \\
$\mathbf{5}$ & 21,10 & $\mathrm{C}$ & 57 & 1.74 & 1 & 1 & 2 \\
$\mathbf{6}$ & 21,1 & $\mathrm{C}$ & 65 & 1.65 & 2 & 2 & 2 \\
$\mathbf{7}$ & 21,10 & $\mathrm{C}$ & 71 & 1.76 & 1 & 1 & 2 \\
$\mathbf{8}$ & 21,3 & $\mathrm{C}$ & 55 & 1.65 & 1 & 1 & 2 \\
$\mathbf{9}$ & 23,11 & $\mathrm{C}$ & 75 & 1.74 & 1 & 1 & 1 \\
$\mathbf{1 0}$ & 23,3 & $\mathrm{C}$ & 70 & 1.8 & 0 & 0 & 0 \\
$\mathbf{1 1}$ & 23,7 & $\mathrm{C}$ & 60 & 1.68 & 1 & 2 & 2 \\
$\mathbf{1 2}$ & 23,5 & $\mathrm{M}$ & 63 & 1.75 & 1 & 1 & 1 \\
$\mathbf{1 3}$ & 24,0 & $\mathrm{C}$ & 70 & 1.72 & 1 & 1 & 1 \\
$\mathbf{1 4}$ & 23,1 & $\mathrm{M}$ & 68 & 1.75 & 2 & 2 & 2 \\
$\mathbf{1 5}$ & 23,8 & $\mathrm{M}$ & 65 & 1.62 & 1 & 2 & 2 \\
$\mathbf{1 6}$ & 22,5 & $\mathrm{M}$ & 99 & 1.7 & 1 & 1 & 2 \\
$\mathbf{1 7}$ & 22,11 & $\mathrm{M}$ & 66 & 1.65 & 1 & 1 & 1 \\
$\mathbf{1 8}$ & 23,11 & $\mathrm{I}$ & 84 & 1.8 & 0 & 2 & 2 \\
$\mathbf{1 9}$ & 22,4 & $\mathrm{M}$ & 45 & 1.65 & 1 & 1 & 2 \\
$\mathbf{2 0}$ & 23,4 & $\mathrm{M}$ & 80 & 1.84 & 2 & 2 & 2 \\
$\mathbf{2 1}$ & 22,6 & $\mathrm{M}$ & 80.5 & 1.65 & 1 & 2 & 2 \\
$\mathbf{2 2}$ & 23,11 & $\mathrm{C}$ & 78.1 & 1.74 & 1 & 1 & 2 \\
$\mathbf{2 3}$ & 23,3 & $\mathrm{M}$ & 102 & 1.65 & 1 & 1 & 2 \\
$\mathbf{2 4}$ & 23,11 & $\mathrm{C}$ & 67.5 & 1.72 & 1 & 1 & 2 \\
$\mathbf{2 5}$ & 22,5 & $\mathrm{M}$ & 84 & 1.72 & 1 & 1 & 1 \\
$\mathbf{2 6}$ & 22,8 & $\mathrm{M}$ & 86.23 & 1.63 & 1 & 1 & 1 \\
$\mathbf{2 7}$ & 23,9 & $\mathrm{C}$ & 64 & 1.7 & 2 & 2 & 2 \\
$\mathbf{2 8}$ & 23,7 & $\mathrm{C}$ & 69 & 1.68 & 1 & 1 & 1 \\
$\mathbf{2 9}$ & 24,1 & $\mathrm{C}$ & 65 & 1.73 & 1 & 1 & 1 \\
$\mathbf{3 0}$ & 23,5 & $\mathrm{C}$ & 65 & 1.7 & 2 & 2 & 2 \\
\hline & & & & & & &
\end{tabular}


Table 4: Normality test results for hand grip strength measurements before and after the experiments for both hands of 30 participants.

\begin{tabular}{cccc|ccc}
\hline & \multicolumn{2}{c|}{ Kolmogorve-Smirnov $^{\mathbf{a}}$} & \multicolumn{3}{c}{ Shapiro-Wilk } \\
Statistic & df & Sig. & Statistic & df & Sig. \\
\cline { 2 - 7 } Initial R & 0.126 & 30 & $0.200^{*}$ & 0.977 & 30 & 0.742 \\
$\mathbf{1 . 0 m} \mathbf{R}$ & 0.120 & 30 & $0.200^{*}$ & 0.960 & 30 & 0.313 \\
$\mathbf{1 . 2 5 m ~ R}$ & 0.148 & 30 & 0.094 & 0.946 & 30 & 0.133 \\
$\mathbf{1 . 5 m ~ R}$ & 0.069 & 30 & $0.200^{*}$ & 0.979 & 30 & 0.795 \\
Initial L & 0.125 & 30 & $0.200^{*}$ & 0.975 & 30 & 0.687 \\
$\mathbf{1 . 0 m} \mathbf{~ L}$ & 0.072 & 30 & $0.200^{*}$ & 0.983 & 30 & 0.898 \\
$\mathbf{1 . 2 5 m ~ L ~}$ & 0.083 & 30 & $0.200^{*}$ & 0.982 & 30 & 0.879 \\
$\mathbf{1 . 5 m ~ L}$ & 0.128 & 30 & $0.200^{*}$ & 0.959 & 30 & 0.289 \\
\hline
\end{tabular}

Table 5: Normality test results for pinch strength measurements before and after the experiments for both hands of 30 participants.

\begin{tabular}{cccc|ccc}
\hline & \multicolumn{2}{c|}{ Kolmogorve-Smirnova } & \multicolumn{3}{c}{ Shapiro-Wilk } \\
& Statistic & df & Sig. & Statistic & df & Sig. \\
\cline { 2 - 7 } Initial R & 0.172 & 30 & 0.023 & 0.933 & 30 & 0.058 \\
$\mathbf{1 . 0 m ~ R ~}$ & 0.114 & 30 & $0.200^{*}$ & 0.948 & 30 & 0.154 \\
$\mathbf{1 . 2 5 m ~ R}$ & 0.154 & 30 & 0.067 & 0.937 & 30 & 0.075 \\
$\mathbf{1 . 5 m ~ R}$ & 0.111 & 30 & $0.200^{*}$ & 0.972 & 30 & 0.608 \\
Initial L & 0.156 & 30 & 0.059 & 0.947 & 30 & 0.143 \\
$\mathbf{1 . 0 m ~ L ~}$ & 0.125 & 30 & $0.200^{*}$ & 0.94 & 30 & 0.092 \\
$\mathbf{1 . 2 5 m ~ L}$ & 0.155 & 30 & 0.064 & 0.936 & 30 & 0.071 \\
$\mathbf{1 . 5 m} \mathbf{~ L}$ & 0.129 & 30 & $0.200^{*}$ & 0.974 & 30 & 0.656 \\
\hline
\end{tabular}

Based on the Shapiro-Wilk test in Table 4, the results of the hand grip strength measurements were summarized in a table where all the hand grip strength data were having the $\mathrm{p}$-value or significance value of more than $0.05(\mathrm{p}>0.05)$. This indicated that the $\mathrm{H}_{0}$ is accepted and the data were all normally distributed. The normal Q-Q plot graphs for each hand grip strengths data were generated and shown in Fig. 9 and Fig. 10.
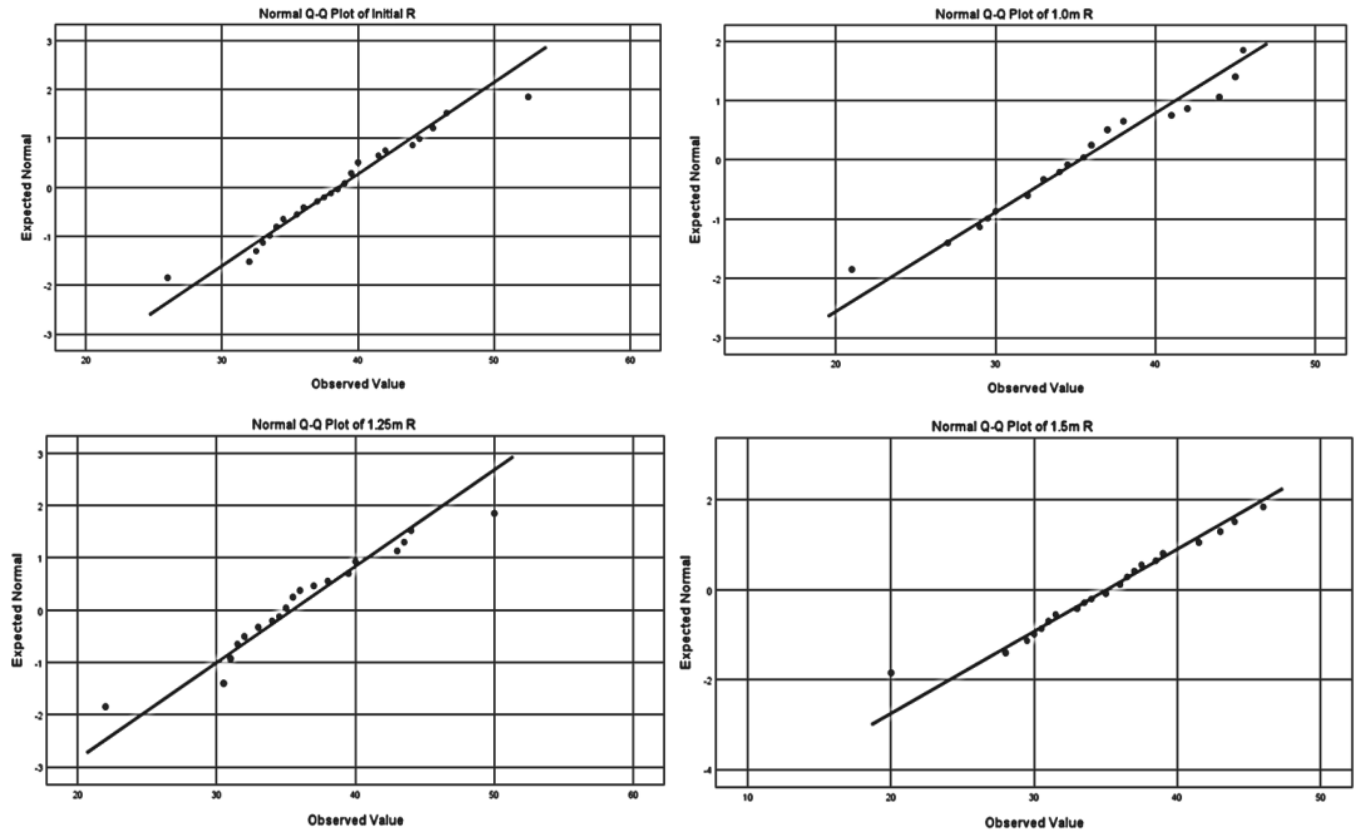

Fig. 9: Normal Q-Q plot graphs for right hand grip strengths data. 
The results of pinch strength measurements were summarized in a table (Table 5) where all the pinch strength data were having the $p$-value or significance value of more than $0.05(\mathrm{p}$ $>0.05)$. This indicated that the $\mathrm{H}_{1}$ is rejected and the data are all normally distributed. The normal Q-Q plot graphs for each pinch strengths data were generated and shown in Fig. 11 and Fig. 12.
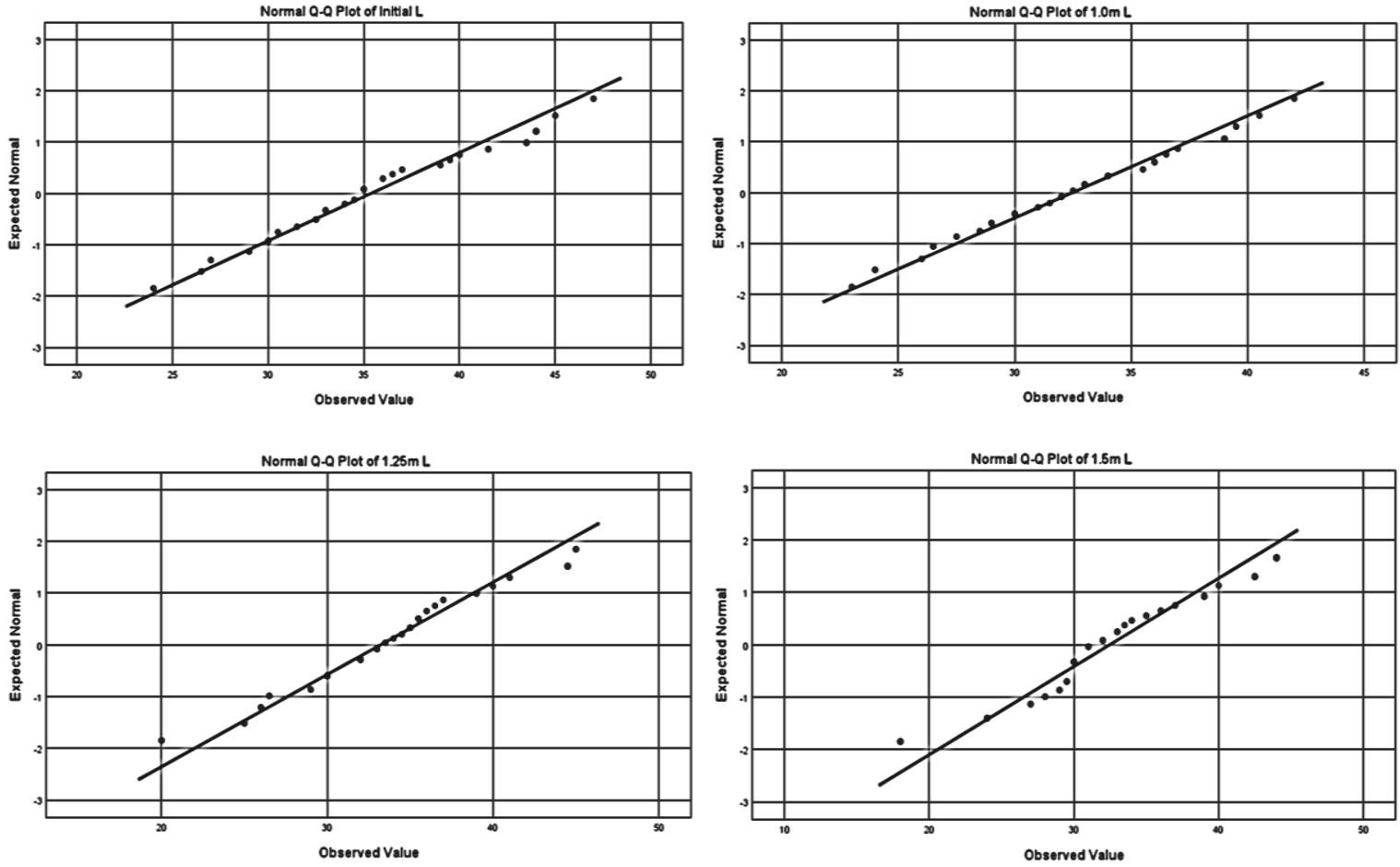

Fig. 10: Normal Q-Q plot graphs for left hand grip strengths data.
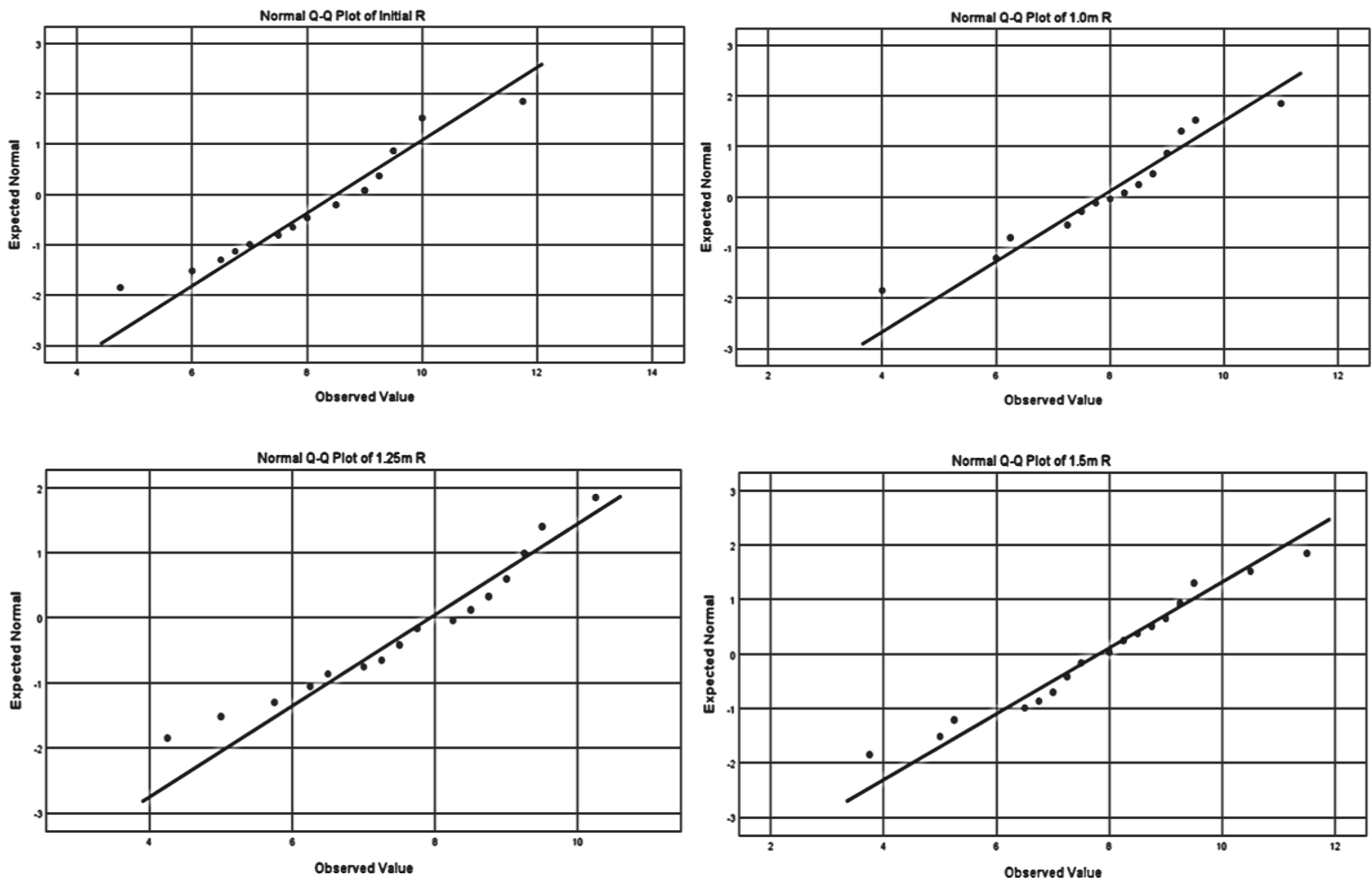

Fig. 11: Normal Q-Q plot graphs for right hand pinch strengths data. 

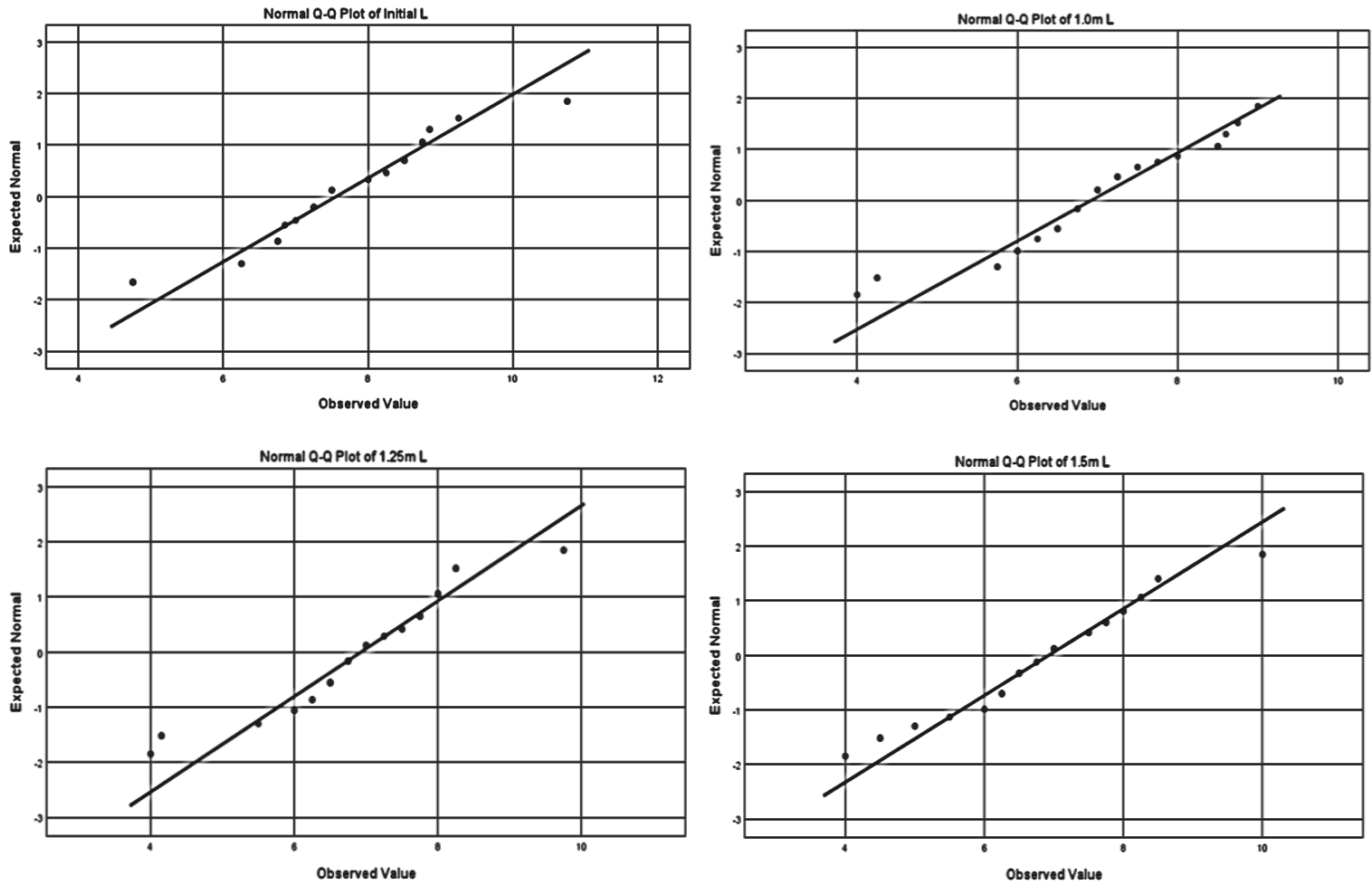

Fig. 12: Normal Q-Q plot graphs for left hand pinch strengths data.

\subsection{Wilks' Lambda Test}

Before comparing in terms of lateral distances, the reduction of forces between the initial hand grip strengths and pinch strengths with the hand grip and pinch strengths after the experiments had to be identified. The Wilks' Lambda test is a test statistic used in MANOVA to test whether there are differences between the means of identified groups of subjects on a combination of dependent variables [16]. Hence, Wilks' Lambda score generated in SPSS had been chosen to identify whether there are any differences between the initial readings and the results readings after the experiments. Both hand grip and pinch strengths data had been investigated separately for two sections which are the right hands (Table 6) and the left hands (Table 7). In this reduction of forces MANOVA test, the hypothesis was fixed as below:

$H_{0}$ : There are no significance differences in the hand grip and pinch strengths data between the initial measurements and after-task measurements.

$H_{1}$ : There are significance differences in the hand grip and pinch strengths data between the initial measurements and after-task measurements.

This hypothesis was set for both right-hand and left-hand hand grip and pinch strength measurements reduction of forces MANOVA tests.

The result displayed by Wilks' Lambda test had shown that the significance value which was the p-value of the data was 0 for both right hand and left hand, which was smaller than $0.05(\mathrm{p}<0)$, indicated that there were statistically significance differences in the hand grip and pinch strength data between the initial measurements and after the lifting task experiment measurements for both hands, therefore reject $\mathrm{H}_{0}$. 
Table 6: Identification of differences between the initial readings and the results readings in right-hand grip and pinch strengths

\begin{tabular}{l|lccccc}
\hline \multicolumn{2}{c}{ Within Subjects Effect } & Value & F & Mypothesis df & Error df & Sig. \\
\hline Distance & Pillai's Trace & 0.571 & 11.583 & 6.000 & 174.000 & 0.000 \\
& Wilks' Lambda & 0.430 & $15.036^{\mathrm{c}}$ & 6.000 & 172.000 & 0.000 \\
& Hotelling's Trace & 1.322 & 18.722 & 6.000 & 170.000 & 0.000 \\
& Roy's Largest Root & 1.320 & $38.267^{\mathrm{d}}$ & 3.000 & 87.000 & 0.000 \\
\hline
\end{tabular}

Table 7: Identification of differences between the initial readings and the results readings in left hand grip and pinch strengths

\begin{tabular}{l|lccccc}
\hline \multicolumn{2}{c}{ Within Subjects Effect } & Value & Fultivariate & Hypothesis df & Error df & Sig. \\
\hline \multirow{3}{*}{ Distance } & Pillai's Trace & 0.522 & 10.246 & 6.000 & 174.000 & 0.000 \\
& Wilks' Lambda & 0.489 & $12.308^{\mathrm{c}}$ & 6.000 & 172.000 & 0.000 \\
& Hotelling's Trace & 1.019 & 14.440 & 6.000 & 170.000 & 0.000 \\
& Roy's Largest Root $^{\text {ab }}$ & 0.995 & $28.868^{\mathrm{d}}$ & 3.000 & 87.000 & 0.000 \\
\hline
\end{tabular}

\subsection{Percentage Reductions}

The calculation of reductions of forces between the initial hand grip and pinch strength readings with the respective distances hand grip and pinch strength readings of $1.0 \mathrm{~m}, 1.25$ $\mathrm{m}$, and $1.5 \mathrm{~m}$ was generated in an Excel file spreadsheet in terms of percentages as shown in Table 8. The calculation of percentage reductions of forces was using the formula as Eq. (1) below.

$$
\frac{R_{L}-R_{I}}{R_{I}} \times 100 \%=\% \text { of reduction }
$$

Where:

$\mathrm{R}_{\mathrm{L}}=$ Larger readings calculated from data measurements,

$\mathrm{R}_{\mathrm{I}}=$ Initial readings of the data.

\subsection{Removal of Outliers}

Besides normality testing, the other assumption needed to be ensured is the exception of outliers for the data before the MANOVA test starts running. The outliers in the data set were categorized as the negative values of the percentage of forces reductions. The data were analyzed manually by excepting all the cases and data set that involved the negative value of the percentage of forces reduction in both hand grip and pinch strengths for both hands by using the filter command in SPSS. There was a total of 7 cases that showed the filter number of " 0 " which had negatives values in the percentage of reduction in hand grip and pinch strength measurements. These cases with filter number " 0 " as shown in Table 8, were considered outliers and did not include in the next stages of the analysis. 
Table 8: Percentages of reduction of forces of hand grip and pinch strength tabulation

\begin{tabular}{|c|c|c|c|c|c|c|c|c|c|c|c|c|}
\hline \multicolumn{3}{|c|}{ Right Hand Grip (\%) } & \multicolumn{3}{|c|}{ Right Pinch (\%) } & \multicolumn{3}{|c|}{ Left Hand Grip (\%) } & \multicolumn{3}{|c|}{ Left Pinch (\%) } & \multirow[t]{2}{*}{ Filter } \\
\hline $1.0 \mathrm{~m}$ & $1.25 \mathrm{~m}$ & $1.5 \mathrm{~m}$ & $1.0 \mathrm{~m}$ & $1.25 \mathrm{~m}$ & $1.5 \mathrm{~m}$ & $1.0 \mathrm{~m}$ & $1.25 \mathrm{~m}$ & $1.5 \mathrm{~m}$ & $1.0 \mathrm{~m}$ & $1.25 \mathrm{~m}$ & $1.5 \mathrm{~m}$ & \\
\hline 2.63 & 5.26 & 7.89 & 8.11 & 5.41 & 0.00 & 10.77 & 1.54 & 7.69 & 0.00 & 11.11 & 3.70 & 1 \\
\hline 7.69 & 13.19 & 34.07 & 2.63 & 5.26 & 2.63 & 8.75 & 11.25 & 12.50 & 7.03 & 13.51 & 16.22 & 1 \\
\hline 17.95 & 20.51 & 7.69 & 21.88 & 12.50 & 9.38 & -3.33 & 0.00 & 0.00 & 14.29 & 7.14 & 10.71 & 0 \\
\hline 7.79 & 19.48 & 3.90 & 2.78 & 5.56 & 22.22 & 16.67 & 0.00 & 0.00 & 2.86 & 11.43 & 2.86 & 1 \\
\hline 2.82 & 7.04 & 7.04 & 2.78 & 5.56 & 2.78 & 4.76 & 4.76 & 4.76 & 6.90 & 3.45 & 10.34 & 1 \\
\hline 1.12 & 11.24 & 12.36 & 10.00 & 5.00 & -5.00 & -2.86 & 0.00 & 4.29 & 1.46 & 1.46 & 12.41 & 0 \\
\hline 18.18 & 3.03 & 15.15 & 2.94 & 14.71 & 11.76 & -1.43 & -2.86 & 14.29 & 7.41 & 3.70 & 0.00 & 0 \\
\hline 13.92 & 11.39 & 6.33 & 5.26 & 2.63 & 7.89 & 13.33 & 0.00 & 0.00 & 12.12 & 6.06 & 3.03 & 1 \\
\hline 4.48 & 8.96 & 5.97 & 16.67 & 0.00 & 19.44 & 5.17 & 10.34 & 6.90 & 18.08 & 15.25 & 15.25 & 1 \\
\hline 10.00 & 0.00 & 8.75 & 22.58 & 3.23 & 9.68 & 8.86 & 7.59 & 6.33 & 6.90 & 3.45 & 13.79 & 1 \\
\hline 14.49 & 4.35 & 2.90 & 3.33 & 16.67 & 10.00 & 13.51 & 10.81 & 8.11 & 8.00 & 12.00 & 20.00 & 1 \\
\hline 9.38 & 3.13 & 12.50 & 0.00 & 3.13 & 9.38 & 0.00 & 1.89 & 9.43 & 3.33 & 3.33 & 6.67 & 1 \\
\hline 5.88 & 5.88 & 8.82 & 11.76 & 8.82 & 2.94 & 2.86 & 4.29 & 17.14 & 3.70 & 0.00 & 7.41 & 1 \\
\hline 1.10 & 5.49 & 8.79 & 7.41 & 3.70 & 3.70 & 6.02 & 3.61 & 3.61 & 11.11 & 3.70 & 3.70 & 1 \\
\hline 10.00 & 11.25 & 6.25 & 0.00 & 0.00 & 0.00 & 13.04 & 7.25 & 13.04 & 11.76 & 5.88 & 8.82 & 1 \\
\hline 12.00 & 8.00 & 6.67 & 5.26 & 7.89 & 5.26 & 18.57 & 8.57 & 5.71 & 5.88 & 2.94 & 5.88 & 1 \\
\hline 16.92 & 3.08 & 9.23 & 23.68 & 21.05 & 15.79 & 21.31 & 1.64 & 3.28 & 25.00 & 21.88 & -3.13 & 0 \\
\hline 0.00 & 5.56 & 0.00 & 7.89 & 2.63 & 2.63 & 6.85 & 5.48 & 9.59 & 17.65 & 8.82 & 11.76 & 1 \\
\hline 5.88 & 8.82 & 10.29 & 0.00 & 4.17 & 12.50 & 1.85 & 7.41 & 11.11 & 10.53 & 12.63 & 5.26 & 1 \\
\hline 5.13 & 2.56 & 20.51 & 7.69 & 23.08 & 23.08 & 6.67 & 17.78 & 28.89 & 10.34 & 27.59 & 24.14 & 1 \\
\hline 13.33 & 4.76 & 16.19 & 10.81 & 10.81 & 13.51 & 7.95 & -1.14 & 11.36 & 6.90 & 6.90 & 10.34 & 0 \\
\hline 0.00 & 0.00 & 2.27 & 10.53 & 2.63 & 10.53 & 17.02 & 4.26 & 6.38 & -3.13 & 25.00 & 12.50 & 0 \\
\hline 2.38 & 4.76 & 1.19 & 6.38 & 12.77 & 2.13 & 15.91 & 19.32 & 0.00 & 16.28 & 9.30 & 6.98 & 1 \\
\hline 8.33 & 1.39 & 5.56 & 14.29 & 10.71 & 25.00 & 0.00 & 0.00 & -9.09 & 10.00 & 13.33 & 6.67 & 0 \\
\hline 19.23 & 15.38 & 23.08 & 15.79 & 10.53 & 21.05 & 4.17 & 16.67 & 25.00 & 15.79 & 21.05 & 15.79 & 1 \\
\hline 13.25 & 15.66 & 6.02 & 0.00 & 0.00 & 11.11 & 3.08 & 10.77 & 9.23 & 0.00 & 5.88 & 0.00 & 1 \\
\hline 6.76 & 5.41 & 2.70 & 3.33 & 0.00 & 3.33 & 5.88 & 0.00 & 17.65 & 3.70 & 3.70 & 7.41 & 1 \\
\hline 3.80 & 6.33 & 16.46 & 6.25 & 6.25 & 6.25 & 8.33 & 2.78 & 11.11 & 3.45 & 6.90 & 3.45 & 1 \\
\hline 24.05 & 22.78 & 2.53 & 2.70 & 2.70 & 0.00 & 12.12 & 19.70 & 6.06 & 6.67 & 13.33 & 6.67 & 1 \\
\hline 3.23 & 6.45 & 1.08 & 8.82 & 0.00 & 2.94 & 9.20 & 5.75 & 2.30 & 0.00 & 8.57 & 5.71 & 1 \\
\hline
\end{tabular}

\subsection{One-way Repeated Measure Multivariate Analysis of Variance (MANOVA)}

This stage of analysis used repeated measure one-way MANOVA for analysis of data in order to achieve the third objective of this project which is to investigate and compare the differences between the hand grip and pinch strength after carrying out lateral lifting tasks in terms of lateral transfer distances. The analysis was carried out using SPSS with the factor of 3 which is \% reduction in $1.0 \mathrm{~m}$; \% reduction in $1.25 \mathrm{~m}$; and \% reduction in $1.5 \mathrm{~m}$ to investigate the relationships between these data. The MANOVA analysis was carried out separately for two sections which the first set was the right-hand grip and pinch strengths data and the second set was the left-hand grip and pinch strengths data with the confidence level of $95 \%$. In this MANOVA test, the hypothesis was fixed as below:

$H_{0}$ : There are no significance differences in the percent reduction of hand grip and pinch strengths between lateral distances of $1.0 \mathrm{~m}, 1.25 \mathrm{~m}$, and $1.5 \mathrm{~m}$.

$H_{1}$ : There are significance differences in the percent reduction of hand grip and pinch strengths between the lateral distances of $1.0 \mathrm{~m}, 1.25 \mathrm{~m}$, and $1.5 \mathrm{~m}$.

This hypothesis was set for both right-hand and left-hand hand grip and pinch strength measurements MANOVA tests. 
Table 9: Percentage reduction of right-hand grip and pinch strength measurements in three different distances

\begin{tabular}{l|lccccc}
\hline \multicolumn{2}{c}{ Within Subjects Effect } & Value & F & Hypothesis df & Error df & Sig. \\
\hline Distance & Pillai's Trace & 0.053 & 0.764 & 4.000 & 112.000 & 0.551 \\
& Wilks' Lambda & 0.947 & $0.759 \mathrm{c}$ & 4.000 & 110.000 & 0.554 \\
& Hotelling's Trace & 0.056 & 0.753 & 4.000 & 108.000 & 0.558 \\
& Roy's Largest Root & 0.053 & $1.482 \mathrm{~d}$ & 2.000 & 56.000 & 0.236 \\
\hline
\end{tabular}

Table 10: Percentage reduction of left-hand grip and pinch strength measurements in three different distances

\begin{tabular}{l|lccccc}
\hline \multicolumn{2}{c}{ Within Subjects Effect } & Value & F & Hypothesis df & Error df & Sig. \\
\hline Distance & Pillai's Trace & 0.045 & 0.505 & 4.000 & 88.000 & 0.732 \\
& Wilks' Lambda & 0.956 & $0.495 \mathrm{c}$ & 4.000 & 86.000 & 0.740 \\
& Hotelling's Trace & 0.046 & 0.484 & 4.000 & 84.000 & 0.747 \\
& Roy's Largest Root & 0.032 & $0.712 \mathrm{~d}$ & 2.000 & 44.000 & 0.496 \\
\hline
\end{tabular}

The Wilks' Lambda test results analyzed and generated by SPSS had shown that the significance value or the $p$-value is 0.554 , which was more than $0.05(p>0.05)$, means that there were no significance differences in reduction percentages for both right-hand grip and pinch strengths (Table 9) between the three distances of $1.0 \mathrm{~m}, 1.25 \mathrm{~m}$, and $1.5 \mathrm{~m}$, hence accept $\mathrm{H}_{0}$.

The Wilks' Lambda test results analyzed and generated by SPSS had shown that the significance value or the $p$-value was 0.74 , which was more than $0.05(p>0.05)$, concluded that there were no significance differences in the percentages of reductions in both left-hand grip and pinch strengths (Table 10) between the three distances of $1.0 \mathrm{~m}, 1.25 \mathrm{~m}$, and $1.5 \mathrm{~m}$, hence accept $\mathrm{H}_{0}$.

\section{DISCUSSION}

\subsection{Reduction of Forces}

Line charts had been plotted from the data collected from the experiment by calculated the mean value of each category of right-hand and left-hand grip readings to identify the pattern for further confirmation. From the line chart (Fig. 13), the right-hand data for both hand grip and pinch strengths were having an obvious decrease trend from the initial readings compared to the others. This can be concluded that there is a reduction of forces between the initial and after the experiment's right-hand grip and pinch strengths readings. From the line chart (Fig. 14), the left-hand data for both hand grip and pinch strengths were having an obvious decrease trend from the initial readings compared to the others. This can be concluded that there is a reduction of forces between initial and after experiments' left-hand grip and pinch strengths readings. 


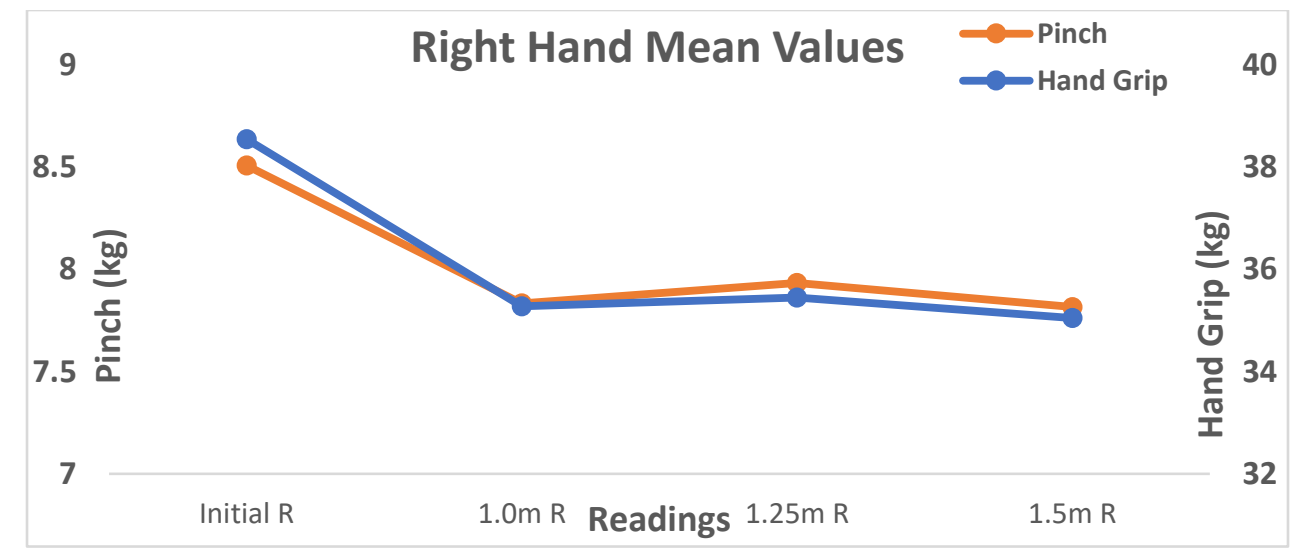

Fig. 13: Line chart for right-hand grip and pinch strengths based on the mean value for each category.

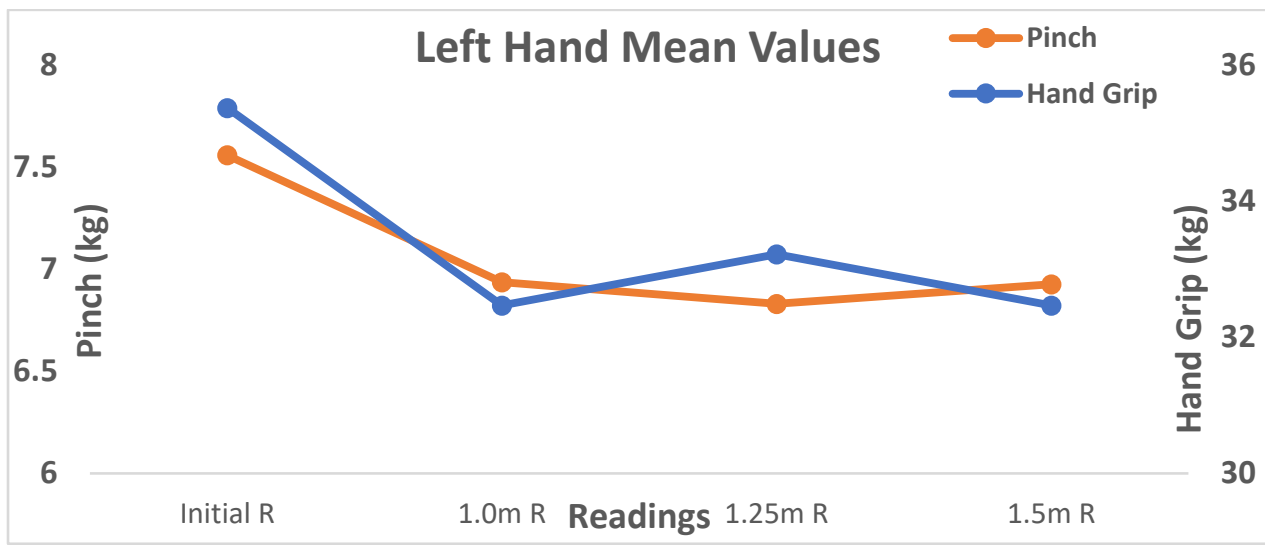

Fig. 14: Line chart for left-hand grip and pinch strengths based on the mean value for each category.

\subsection{Transfer Distances}

The overall results generated by using the one-way repeated measure MANOVA test and graphical charts had indicated that there was a high significance reduction of forces between the initial and the after experiments data for both hand in hand grip and pinch strengths. However, when the relationship between the three types of distances with two dependent variables of hand grip and pinch strengths were tested, the results showed that there were no significance differences in the relationship. This statistical result indicated that distances (1.0 $\mathrm{m}, 1.25 \mathrm{~m}$, and $1.5 \mathrm{~m}$ ) will not affect the hand grip and pinch strengths during the lateral lifting tasks.

The surveys carried out in each participant had shown the perceptions of participants on the distance that caused pain in hands (Fig. 15) and fingers (Fig. 16) during lateral lifting tasks during the experiment. The result showed in Figure 11 indicated that there were $56.7 \%$ of people disagreed that at $1.0 \mathrm{~m}$ distance would cause pain in hand, while $43.3 \%$ of people agreed that $1.5 \mathrm{~m}$ distance would cause pain in hand. The high percentage for disagreed and neutral score at $1.25 \mathrm{~m}$ of $43.3 \%$ respectively showed that the majority of the people did not felt pain when transferring load at $1.25 \mathrm{~m}$. The percentage of disagreed and neutral at a distance of $1.5 \mathrm{~m}$ was in a total of $56.6 \%$, which is higher than the percentage of agreed, which is $43.3 \%$, indicated that more than half of the participants did not felt pain in hand at $1.5 \mathrm{~m}$ 
distance. The result had clearly concluded that the majority of participants did not feel any pain in either of these three distances during the lateral lifting tasks experiment.

The result in Fig. 16 had shown that the highest percentage for all type of distances were from the disagreed score, which was $63.3 \%$ at $1.0 \mathrm{~m}, 50 \%$ at $1.25 \mathrm{~m}$ and $43.3 \%$ at $1.5 \mathrm{~m}$. The neutral score for three distances had a consistent pattern which laid around $20 \%$ to $30 \%$. The agreed score had an inclined trend pattern followed the sequence of $1.0 \mathrm{~m}, 1.25 \mathrm{~m}$, and $1.5 \mathrm{~m}$ which had indicated that there were less than $40 \%$ of participants agreed that they felt pain in fingers during lifting tasks in these distances. The result had clearly shown that majority of the participants did not felt pain in fingers in either these three distances during lateral lifting tasks experiments.

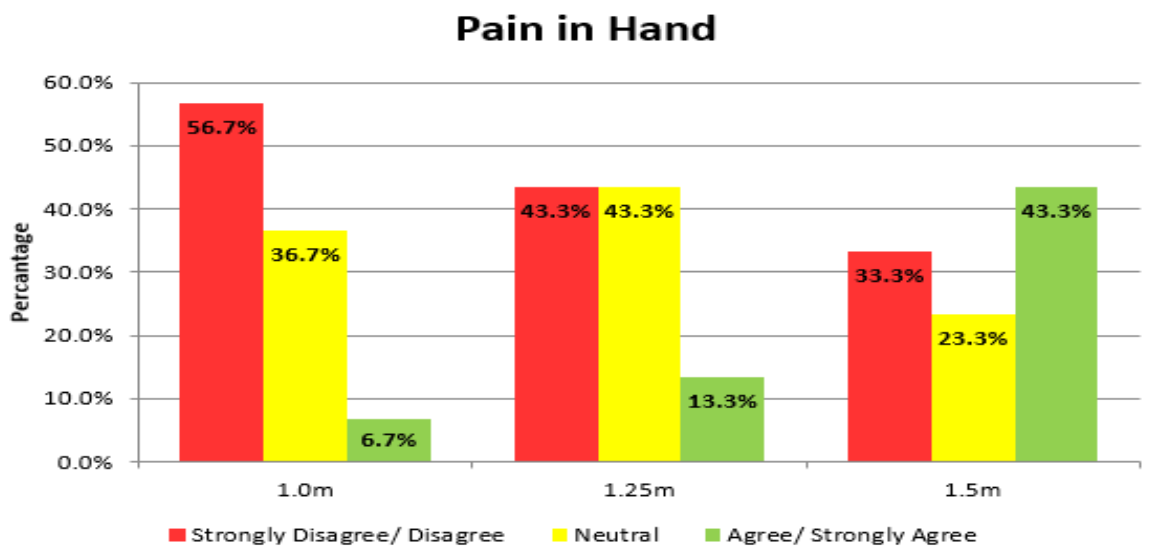

Fig. 15: Perceptions of participants on the distance that cause pain in hands during lateral lifting tasks.

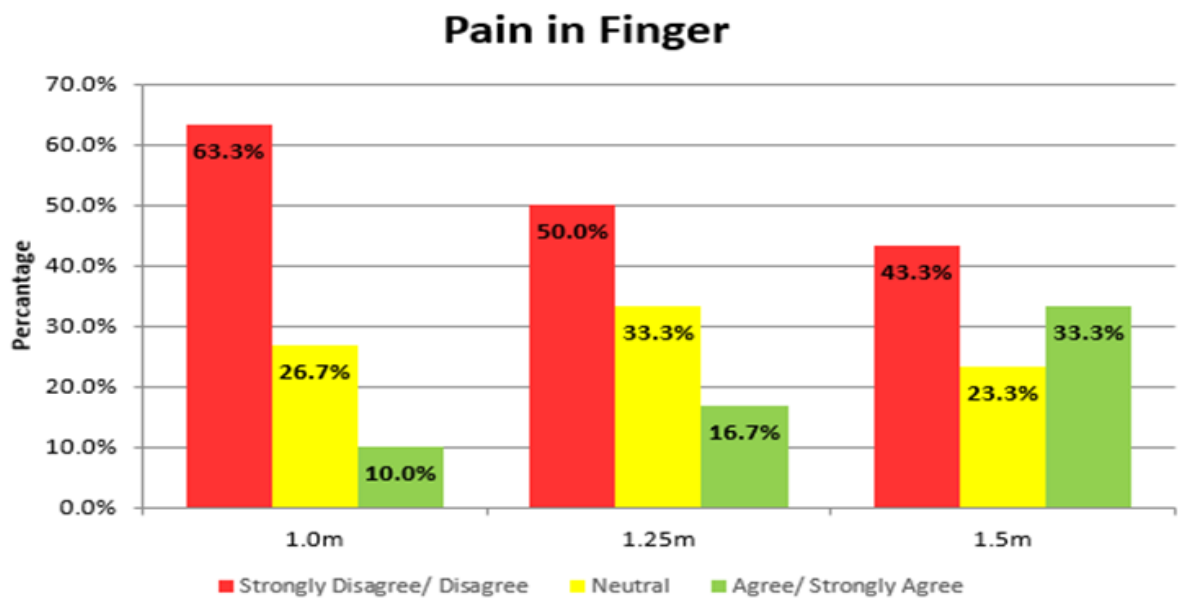

Fig. 16: Perceptions of participants on the distance that cause pain in fingers during lateral lifting tasks.

\subsection{Transfer Postures}

During the experiment, the transfer process of every participant was observed to identify the way and the postures of participants carried out lateral lifting tasks. Based on Vengata et al. [17] stated that the hand grip strengths and its evaluations are affected by several factors such as age, gender, posture, fatigue, wrist, and forearm position. For example, the difference in grip strength in different posture caused by the change in length of the muscle. Lee and 
Sechachalam also indicated that the wrist position can affect one's hand grip strength due to flexion [18].

\section{Posture During Lateral Lifting Task}

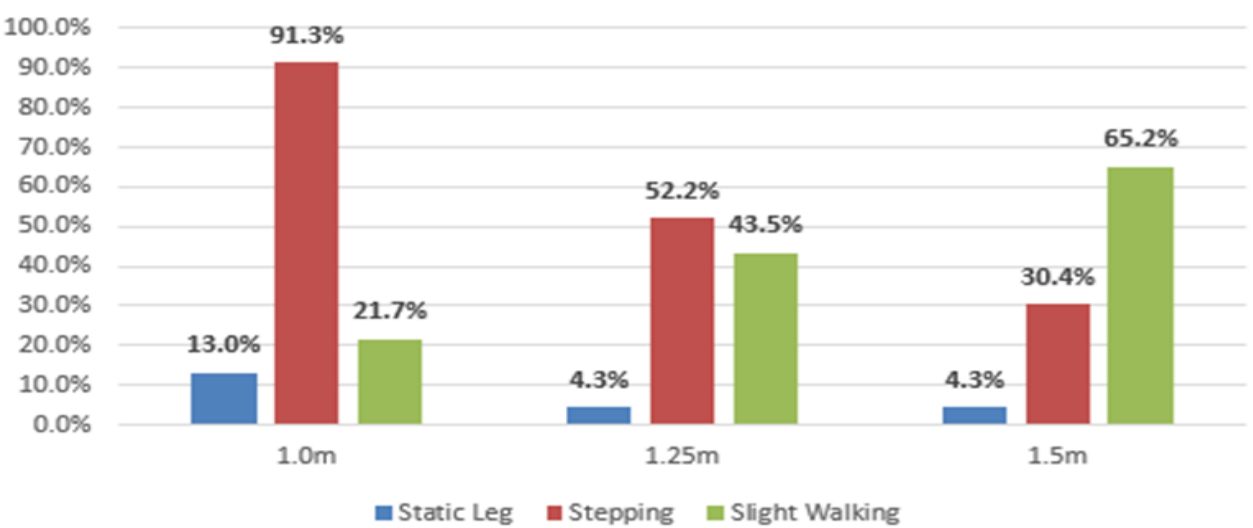

Fig. 17: The posture of participants during lateral lifting tasks.

The posture of the participants during experiments transferring load in $1.0 \mathrm{~m}, 1.25 \mathrm{~m}$, and $1.5 \mathrm{~m}$ was observed and tabulated in an Excel file to generate a graph in Fig. 17. The result showed that the majority of the participants were stepping and slight walking during the transferring process. For every distance, the percentages of participants that were remained static when transferring the load were not more than $13 \%$. For the distance of $1.0 \mathrm{~m}, 91.3 \%$ of participants were stepping and $21.7 \%$ of participants were slight walking during the transfer process. For distance $1.25 \mathrm{~m}$, about half of the participants were stepping while $43.5 \%$ of participants were slight walking during the transfer process. For $1.5 \mathrm{~m}$, the percentage of participants that stepping was continuously decreased to $30.4 \%$, while the percentage of participants that slight walking was increased to $65.2 \%$.

The posture of stepping and slight walking would lower the participants tiring and fatigue level during lateral lifting tasks, since participants were majority stepping and walking during the lifting tasks, hence the result of reduction of hand grip and pinch strength in between three distance did not have significance differences. The high percentage of participants were stepping and slight walking in the lateral transfer tasks was influenced by the knowledge level of the participants themselves towards lateral lifting tasks.

The line graphs for the mean values of hand grip and pinch strength measurements for each distance in static leg, stepping, and slight walking postures of the participants were also generated to investigate the pattern and the trend of the graphs (Fig. 18). The results showed that the patterns were not consistence, and this had indicated that the leg and body posture did not contribute any large effect on the hand grip and pinch strengths measurements in $1.0 \mathrm{~m}$, $1.25 \mathrm{~m}$, and $1.5 \mathrm{~m}$ transfer distances.

\subsection{Limitation}

This study had a few limitations, such as the experiments only involved single gender which is the majority gender that performing material handling tasks in every sector, and only right-handed males can participate in the experiment. The experiment can be expanded further which involved two genders and left-handed people can also participate in the experiments. The relationship between the dominant hands and genders with lateral lifting tasks can be analyzed. 

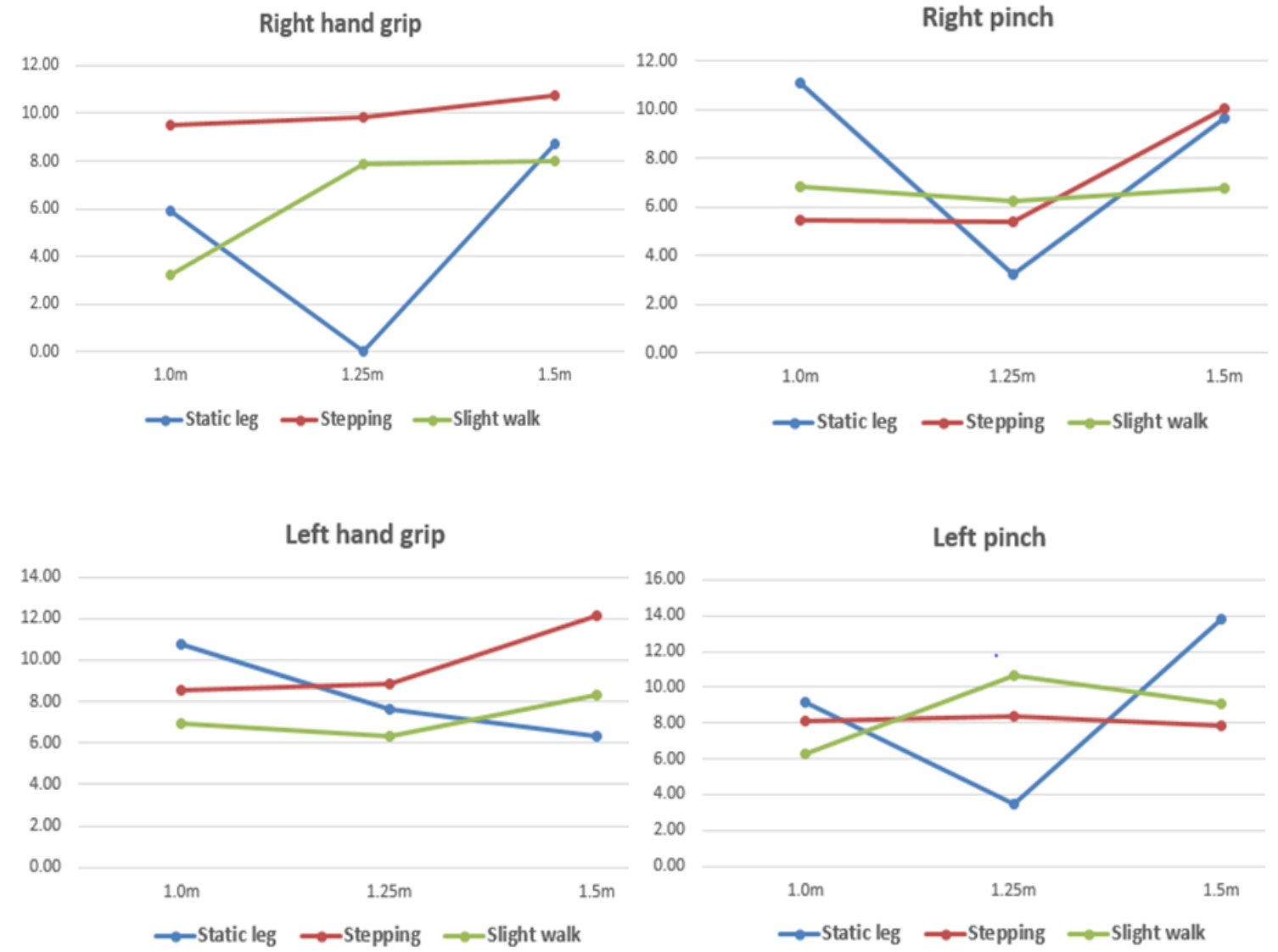

Fig. 18: The mean value of hand grip and pinch measurements for each distance in static leg, stepping and slight walking postures.

Besides, the experiments only tested on a group of participants, which could not give a better chance to make comparisons between different groups of people with specific characteristics. Increased in the number of groups to be testes based on different characteristics such as one group is educated, and the others are not can be further research to identify whether the postures and the way they carried out lateral lifting tasks are different.

Moreover, the experiment involved in this study was only tested one independent variable which is the transfer distance due to the time issues. The weight of the load can also be analyzed to see the relationship between the load weights and the transfer distances with the hand grip and pinch strengths. The factor of presence of proper grip of the load can also be investigated in two groups of participants to identify the differences in hand grip and pinch strength measurements. The postures or the way participants carry the loads can also be observed or identified to investigate the relationship between the transfer distances.

Lastly, the frequency of lateral transfer tasks in this study for the experiment only involved 6 cycles per distance. For the next research, the frequency of transferring loads was suggested to increase the frequency to identify the relationship of the repetitive factor with the hand grip and pinch strengths.

\section{CONCLUSION}

The experimental study involved the participants to carry out six cycle lateral lifting tasks each in three different distances of $1.0 \mathrm{~m}, 1.25 \mathrm{~m}$, and $1.5 \mathrm{~m}$ following the counterbalancing 
sequences. The experiment was carried out in the condition of participants did not fatigue; hence participants were given one minute to rest before proceeding to the next tasks. The observations on the posture of the participants during the experiments also indicated that most of the participants were stepping and slight walking during the transfer process, hence the chances of exhausted occurred in hand were highly reduced. The survey form results also indicated that the participants did not fatigue and did not felt pain in hand during the experiments. The analysis of the results in this study had concluded that the transfer distance of $1.0 \mathrm{~m}, 1.25 \mathrm{~m}$, and $1.5 \mathrm{~m}$ during lateral lifting tasks does not affect the hand grip and pinch strengths. However, further research was needed to identify whether the other distances especially longer distance will affect the hand grip and pinch strengths.

\section{ACKNOWLEDGEMENTS}

The authors would like to thank Universiti Teknikal Malaysia Melaka for providing the Jamar Hand Dynamometer and Pinch Meter for the experiments. Many thanks as well to all the participants for the cooperation and contributions in this study. This work was supported by the Faculty of Manufacturing Engineering Universiti Teknikal Malaysia Melaka. This research did not receive any specific grant from funding agencies in the public, commercial, or not-for-profit sectors.

\section{REFERENCES}

[1] Shriniket M. (2018) 992 Ergonomic risk evaluation in an automobile industry for preventing musculoskeletal problems. In 32nd Triennial Congress of the International Commission on Occupational Health (ICOH): 29 April-4 May 2018; Dublin. Edited by BMJ Publishing Group Ltd; pp A267. http://dx.doi.org/10.1136/oemed-2018-ICOHabstracts.756.

[2] Advisory Committee from Hospital Pharmacy. (2018) Summaries of safety labeling changes approved by FDA- Boxed warnings highlights July-September 2017. 53(1): 18-24. doi: $10.1177 / 0018578717743812$.

[3] Phil H, Ferrett Ed. (2011) Workplace hazards and risk control. In introduction to health and safety at work. $5^{\text {th }}$ Ed. London, Routledge; pp 193-227. doi: 10.4324/9780080970714.

[4] Veselina N, Iskra SM. (2018) Work-related musculoskeletal disorders (WMSDs): risk factors, diagnosis and prevention. Scripta Scientifica Salutis Publicae, 4: 15. doi: 10.14748/sssp.v4i0.5076.

[5] Tae HK, Jay PM, Monica RW, Steven AL. (2014) The effects of transfer distance on spine kinematics when placing boxes at different heights. Applied Ergonomics, 45(4): 936-942. https://doi.org/10.1016/j.apergo.2013.11.010.

[6] Charles DR. (2008) Office ergonomics. Industrial safety and health for administrative services. CRC Press, $1^{\text {st }}$ edition; pp 297-312.

[7] Copsey SM, Elke S. (2018) 1167 Mainstreaming gender into occupational safety and health (osh) practice. Women, Health and Work. BMJ Publishing Group Ltd, doi: 10.1136/ oemed-2018-icohabstracts.1494.

[8] Advisory Committee from The Center For Construction (CPWR). (2018) Fatal and nonfatal injuries - Musculoskeletal disorders in construction and other industries. CPWR, $6^{\text {th }} \mathrm{Ed}$.

[9] Snooks H, Foster T, Nicholl J. (2004) Results of an evaluation of the effectiveness of triage and direct transportation to minor injuries units by ambulance crews. Edited by Emerg MJ, 21(1): 105-111. doi: 10.1186/isrctn21222541.

[10] Ven-Stevens LAWVD, Maud JLG, Ruud WS, Ton ARS. (2015) Instruments for assessment of impairments and activity limitations in patients with hand conditions: A European Delphi study. Journal of Rehabilitation Medicine, 47(10): 1-9. doi: 10.2340/16501977-2015. 
[11] Jaffar N, Abdul-Tharim AH, Mohd-Kamar IF, Lop NS. (2011) A literature review of ergonomics risk factors in construction industry. Procedia Engineering, 20: 89-97. doi:10.1016/j.proeng.2011.11.142.

[12] Mathiowetz V, Keren WBS, Gloria VBS, Nancy KBS. (1984) Reliability and validity of grip and pinch strength evaluations. The Journal of Hand Surgery, 9(2): 222-226, doi: 10.1016/S0363-5023(84)80146-X.

[13] Petersen P, Petrick M, Connor H, Conklin D. (1989) Grip strength and hand dominance: Challenging the 10\% rule. American Journal of Occupational Therapy, 43(7): 444-447. doi: 10.5014/ajot.43.7.444.

[14] Zeelenberg R, Pecher D. (2015) A method for simultaneously counterbalancing condition order and assignment of stimulus materials to condition. Behavior Research Methods, 47(1): 127133, doi: 10.3758/s13428-014-0476-9.

[15] Nornadiah MR, Bee WY. (2011) Power comparisons of Shapiro-Wilk, Kolmogorov-Smirnov, Lilliefors and Anderson-Darling tests. Journal of Statistical Modeling and Analytics, 2(1): 2133.

[16] Helen P, Vanessa S, Elizabeth W, Heidi R. (2000) A comparison of nursing competence of graduates and diplomates from UK nursing programmes. Journal of Clinical Nursing, 9(3): 369-381. https://doi.org/10.1046/j.1365-2702.2000.00331.x.

[17] Vengata SM, Subramanian GS, Isaac J. (2015) Factors affecting hand grip strengths and its evaluation: A systemic review. International Journal of Physiotherapy and Research, 3(6): 1288-1293.

[18] Lee JA, Sechachalam S. (2016) The effect of wrist position on grip endurance and grip strength. The Journal of Hand Surgery, 41(10): 367-373. doi: 10.1016/J.JHSA.2016.07.100. 